\title{
Anthocyanins in Floral Colors: Biosynthesis and Regulation in Chrysanthemum Flowers
}

\author{
Manjulatha Mekapogu ${ }^{1}$, Bala Murali Krishna Vasamsetti ${ }^{2}$ (D) Oh-Keun Kwon ${ }^{1}$, \\ Myung-Suk Ahn ${ }^{1}$, Sun-Hyung Lim $^{3}$ and Jae-A Jung ${ }^{1, * \mathbb{D}}$ \\ 1 Floriculture Research Division, National Institute of Horticultural \& Herbal Science, Rural Development \\ Administration, Wanju 55365, Korea; manjubio7@gmail.com (M.M.); kok5510@korea.kr (O.-K.K.); \\ ahnms@korea.kr (M.-S.A.) \\ 2 Chemical Safety Division, National Institute of Agricultural Sciences, Rural Development Administration, \\ Wanju 55365, Korea; vbmk84@gmail.com \\ 3 Division of Horticultural Biotechnology, School of Biotechnology, Hankyoung National University, \\ Anseong 17579, Korea; limsh2@hknu.ac.kr \\ * Correspondence: jabisung@korea.kr
}

Received: 21 August 2020; Accepted: 4 September 2020; Published: 7 September 2020

\begin{abstract}
Chrysanthemum (Chrysanthemum morifolium) is an economically important ornamental crop across the globe. As floral color is the major factor determining customer selection, manipulation of floral color has been a major objective for breeders. Anthocyanins are one of the main pigments contributing to a broad variety of colors in the ray florets of chrysanthemum. Manipulating petal pigments has resulted in the development of a vast range of floral colors. Although the candidate genes involved in anthocyanin biosynthesis have been well studied, the genetic and transcriptional control of floral color remains unclear. Despite advances in multi-omics technology, these methods remain in their infancy in chrysanthemum, owing to its large complex genome and hexaploidy. Hence, there is a need to further elucidate and better understand the genetic and molecular regulatory mechanisms in chrysanthemum, which can provide a basis for future advances in breeding for novel and diverse floral colors in this commercially beneficial crop. Therefore, this review describes the significance of anthocyanins in chrysanthemum flowers, and the mechanism of anthocyanin biosynthesis under genetic and environmental factors, providing insight into the development of novel colored ray florets. Genetic and molecular regulatory mechanisms that control anthocyanin biosynthesis and the various breeding efforts to modify floral color in chrysanthemum are detailed.
\end{abstract}

Keywords: breeding; genetic manipulation; ornamental plants; petal color; plant pigments

\section{Introduction}

Flowers are beautiful and vital organs, which provide eye-catching attributes to plants with their varied colors and morphology. Among flower attributes, petal color is economically and biologically important [1-3]. Floral color greatly influences customer choice of cut flowers, potted flowers, and garden flowers. Floral hue also plays a key role in attracting pollinators for reproduction. In addition to attracting pollinators, pigments protect against photo-oxidative damage, and provide resistance to biotic and abiotic stresses [4]. Therefore, the manipulation of floral color is an important goal for ornamental plant breeders.

The global cut flower market is dominated by major ornamental flowers, including rose, chrysanthemum, carnation, lily, and gerbera, which have commercial value and provide a high yield. Chrysanthemum is one of the most popular ornamental plants and is the second most economically important cut flower in the global market [5]. The quality of chrysanthemum flowers is evaluated 
based on its color, and hence color is important for the determination of commercial value $[6,7]$. The compound inflorescence of the chrysanthemum flower has central disc florets, which are usually yellow or green, whereas the marginal ray florets present a wide range of colors, including purple, green, red, pink, orange, and white [8]. Although floral color in wild chrysanthemum is limited to yellow, white, and pink, advances in chrysanthemum breeding have enabled the development of a broad spectrum of floral colors, including red, orange, dark red, and green.

Floral color intensity is mainly due to the accumulation of a single pigment or a combination of pigments, and flowers with no pigments have also been reported [8]. Plant biproducts, classified broadly as carotenoids and flavonoids, underly the colorful pigmentation of flower petals [9]. Carotenoids, classified as carotenes and xanthophylls, are the most widely distributed pigments, and are cyclization-produced organic molecules of a C40 polyene backbone with an ionone ring [10]. Carotenoids can impart yellow, orange, and bright red colors and their specific compositions vary widely in the petals of ornamental flowers. Flavonoids are the largest class of secondary metabolites that are widely distributed in the plant kingdom [11,12]. Flavonoids are characterized by two phenyl rings, and a heterocyclic $\mathrm{C}_{15}$ carbon ring as the backbone. Based on the specific structure and the functional group present, flavonoids can be divided into several groups: chalcones, flavanones, flavones, flavanonols, flavonols, flavanols, and anthocyanins. This widespread and important group of pigments contributes to a wide spectrum of petal colors, from pale yellow to orange, red, blue, purple, and magenta. In particular, anthocyanins are the largest group of pigments among flavonoids, which impart diverse colors in flower, from orange to red and from purple to blue [13]. Major pigments that impart floral colors are listed in Table 1. Chrysanthemum cultivars are considered a good source of anthocyanin for commercial-level extraction, since they contain numerous flowers in a single plant and a wide range of floral colors [14] Therefore, a deeper understanding of the molecular mechanism underlying anthocyanin regulation that influences petal color formation would facilitate more efficient breeding efforts to generate novel colors and patterns in chrysanthemum flowers. Thus, this review focuses on ray petal color formation in chrysanthemum, particularly that mediated by anthocyanin biosynthesis. The role of anthocyanins in plant pollinator attraction and stress tolerance is discussed. This review also provides a brief and cumulative overview of recent progresses in the study of genetic and environmental regulatory factors that influence anthocyanin biosynthesis. Moreover, a summary on the breeding efforts aiming at modifying and developing novel floral hues in chrysanthemum is presented. 
Table 1. Major pigments in plants that impart color to floral petals.

\begin{tabular}{|c|c|c|c|c|}
\hline Pigment & Class & Structure & Compound & References \\
\hline \multirow{2}{*}{ Carotenoids } & Carotenes & & $\begin{array}{c}\text { Lycopene, } \alpha \text {-carotene, } \beta \text {-carotene, } \\
\gamma \text {-carotene, etc. }\end{array}$ & [10] \\
\hline & Xanthophylls & & $\begin{array}{l}\text { Lutein, zeaxanthin, violaxanthin, } \\
\text { neoxanthin, etc. }\end{array}$ & [10] \\
\hline \multirow{7}{*}{ Flavanoids } & Chalcones & & $\begin{array}{l}\text { Chalconaringenin, arbutin, phloretin, } \\
\text { phloridzin }\end{array}$ & [11] \\
\hline & Flavanones & & $\begin{array}{c}\text { Naringenin, eriodictyol, hesperetin, } \\
\text { homoeriodictyol }\end{array}$ & [11] \\
\hline & Flavones & & Apigenin, luteolin, tangeritin & [11] \\
\hline & Flavanonols & & Taxifolin, dihydrokaempferol & [11] \\
\hline & Flavonols & & Quercetin, kaempferol, myricetin & [11] \\
\hline & Flavanols & & Catechin, epicatechin, apiforol, lueoforol & [11] \\
\hline & Anthocyanins & & $\begin{array}{l}\text { Cyanidin, pelargonidin, delphinidin, malvidin, } \\
\text { peonidin, petunidin, etc. }\end{array}$ & [13] \\
\hline
\end{tabular}




\section{Anthocyanins in Pollination Ecology}

Floral color and scent are the traits that attract pollinators. Floral color acts as a sensory signal by endorsing the quality and quantity of floral rewards [15]. Pollinators exhibit a natural preference towards specific floral attributes, which they associate with the flower that provides food sources such as nectar and pollen [16]. Floral color provides flowers with radiance and attractiveness, which can act as a visualization signal to the pollinators, increasing the number of pollinator visits and thereby increasing the pollinator foraging efficiency and reproductive success. In some cases, flowers change their color, allowing the pollinators to avoid unrewarding and old flowers and to select rewarding flowers. This reduces repeated visits to the same flower and thus increase the pollination efficiency of the visitors [17,18]. A specific class of pollinators is usually associated with specific floral colors, which might be dependent on the perception of the pollinators. The majority of insect pollinators possess photoreceptors, which detect the UV part of the light spectrum as well as the visible spectrum $[19,20]$. UV light is reflected by the flowers of angiosperms [21]. UV-absorbing nectar guides aid the insects to rightly orient to obtain the nectar [22]. These UV patterns on the flower help the proper landing and foraging of the pollinator [23]. Attempts have been made to assess pollinator discrimination towards different colored petals in flowers. Notably, flowers with different pigments are attractive to different classes of pollinators. Bradshaw and Schemske (2003) [24] showed that bumblebees and hummingbirds clearly distinguished the near-isogenic lines of Mimulus, which only differed in floral color. Plants of Mimulus lewisii, which possess a pink flower due to the accumulation of anthocyanins, are primarily pollinated by bumblebees, while Mimulus cardinalis, characterized by orange/red colored flowers due to the combined accumulation of anthocyanins and carotenoids, are pollinated by hummingbirds. Additionally, when the yellow upper (YUP) locus, which is responsible for carotenoid accumulation was introgressed from each of these Mimulus species into other background, it resulted in orange-colored $M$. lewisii flowers and deep pink-colored M. cardinalis flowers. Orange M. lewisii flowers were then visited by more hummingbirds than bumblebees, and the pink $M$. cardinalis flowers were visited by more bumblebees than hummingbirds. Hence, it is likely that floral color including anthocyanin accumulation, plays a major role in the attraction of specific pollinators.

\section{Anthocyanins in Stress Tolerance}

Apart from the floral parts, anthocyanins often occur transiently in the root, stem, and leaf tissues of plants at specific developmental stages in response to environmental factors, including UV radiation, cold temperatures, and water stress. Although the biosynthesis and molecular control of anthocyanin in the floral parts have been well studied, the adaptive advantages of anthocyanin accumulation in non-reproductive tissues are unclear. The environmental induction of anthocyanin accumulation in the vegetative tissues reflects the response of the plant to environmental factors, including biotic and abiotic stresses [25]. Different stresses induce different kinds of anthocyanins with a change in the pattern of decoration, suggesting that these anthocyanins have unique purposes during stress. Arabidopsis grown under different abiotic stress conditions was found to accumulate high levels of total anthocyanins, with each stress condition inducing a different kind of anthocyanin [26]. Overexpression of RsMYB1, a positive regulator of anthocyanin biosynthesis, was found to induce the expression of genes related to metal detoxification in addition to enhanced anthocyanin accumulation in petunia, suggesting an important role of anthocyanins in metal detoxification in horticultural crops [27]. Furthermore, increased anthocyanin levels enabled petunia plants overexpressing the RsMYB1 gene to tolerate low $\mathrm{pH}$ stress [28]. In chrysanthemum, R2R3-MYB transcription factors, which are involved in the regulation of anthocyanin biosynthesis, have also been linked to abiotic stress tolerance. Heterologous expression of $C m M Y B 2$ was found to enhance the salinity and drought stress tolerance of Arabidopsis. CmMYB2 increased the efficient ABA synthesis and more effective ABA signaling. Collectively, these processes induced the higher expression levels of some key abiotic stress responsive genes in transgenic Arabidopsis. Hence, CmMYB2 is proposed as a promising candidate gene for abiotic stress tolerance in chrysanthemum [29]. 


\section{Anthocyanin Biosynthesis in Chrysanthemum Flowers}

Anthocyanins are plant secondary metabolites that have been well characterized in terms of their chemistry and structure [30]. These water-soluble pigments are localized in various organs, including leaves, flowers, and fruit, and are the main pigments that impart pink to purple-red colors in chrysanthemum ray petals, whereas a lack of their accumulation results in white ray florets [31,32]. Anthocyanins are the sugar-containing counterparts (3-glucosides) of anthocyanidins. They possess a characteristic $\mathrm{C}_{6}-\mathrm{C}_{3}-\mathrm{C}_{6}$ carbon skeleton and can be subdivided into anthocyanidin sugar-free aglycones and anthocyanin glycosides. Anthocyanidins consist of two aromatic benzene rings separated by an oxygenated heterocycle [33]. Of the 20 anthocyanidins identified, only six are common in plants [34]. Determination of flower petal color is largely dependent on the number of hydroxyl groups present in the skeletal B-ring, and the color shifts towards blue as the number of hydroxyl groups increases [33]. Anthocyanin color has been associated with changes in sugar moieties and organic acids in anthocyanidins, which form anthocyanins in a species-specific manner [9]. Generally, these anthocyanidin pigments accumulate as glycosylated forms called anthocyanins, since anthocyanidins are inherently more unstable. Structurally, these anthocyanins are characterized by carbon 3 linked through oxygen to a sugar residue, which is more frequently glucose, and also with other sugar moieties like galactose, xylose, rhamnose, and arabinose. The most prevalent anthocyanidins distributed in flowers are cyanidin, delphinidin, and pelargonidin. Of these three basic groups of anthocyanins, ray florets of chrysanthemum mainly accumulate cyanidin-based anthocyanins, such as cyanidin-3-O- (6"-O-malonyl) glucoside and cyanidin $3-O-\left(3^{\prime \prime} 6^{\prime \prime}\right.$-di-O-malonyl) glucoside [8,35-37]. Early reports suggested that the pink to purple-red color in cyanidin-based ray petals depends on the cyanidin content [38]. Notably, chrysanthemums do not naturally accumulate delphinidin-based anthocyanins [39]. However, transgenic studies in the past decade have produced purple/violet transgenic chrysanthemum flowers, likely to be due to the accumulation of delphinidin-based anthocyanins, including delphinidin 3-(6"-malonyl) glucoside and delphinidin 3-( $3^{\prime \prime}, 6^{\prime \prime}$-dimalonyl) glucoside in flower petals [39]. The generation of blue-colored chrysanthemums is further discussed in Section 8.5. Recently, transgenic chrysanthemum with novel blue petals has been generated, with the accumulation of delphinidin-based anthocyanin, delphinidin 3-O-(6"-O-malonyl) glucoside-3', $5^{\prime}$-di-O-glucoside, and co-pigmentation found in blue petals [40]. Anthocyanin biosynthesis is conserved across species; however, the mechanism of anthocyanin degradation remains unclear. [33,41,42]. Generally, anthocyanin biosynthesis involves sub-sequential metabolic pathways, including one molecule of 4-coumaroyl CoA, derived from the general phenylpropanoid pathway and three molecules of malonyl CoA derived from fatty acid metabolism (Figure 1).

As precursors for flavonoid biosynthesis, 4-coumaroyl $\mathrm{CoA}$, and malonyl $\mathrm{CoA}$ are converted to naringenin chalcone by chalcone synthase (CHS) and to dihydrokaempferol by chalcone isomerase (CHI) and flavanone 3-hydroxylase (F3H). Dihydroflavanol 4-reductase (DFR) and anthocyanidin synthase (ANS) are two enzymes that are required to convert dihydrokaempferol to pelargonidin, a pink anthocyanidin. The B-ring of dihydrokaempferol is further hydroxylated either to cyanidin by flavonoid $3^{\prime}$-hydroxylase $\left(\mathrm{F} 3^{\prime} \mathrm{H}\right)$ or to delphinidin by flavonoid $3^{\prime} 5^{\prime}$-hydroxylase $\left(\mathrm{F} 3^{\prime} 5^{\prime} \mathrm{H}\right)$ (Figure 1). Delphinidin-based anthocyanins do not accumulate in chrysanthemum due to the absence of genes encoding $\mathrm{F}^{\prime} 5^{\prime} \mathrm{H}$ [34]. Therefore, only cyanidin-based anthocyanins are reported to accumulate in chrysanthemum ray petals [8]. Several studies have reported that the accumulation of cyanidin, pelargonidin, and delphinidin generally imparts pink to red-purple [43], orange to red [44], and purple to blue [45] respectively. 


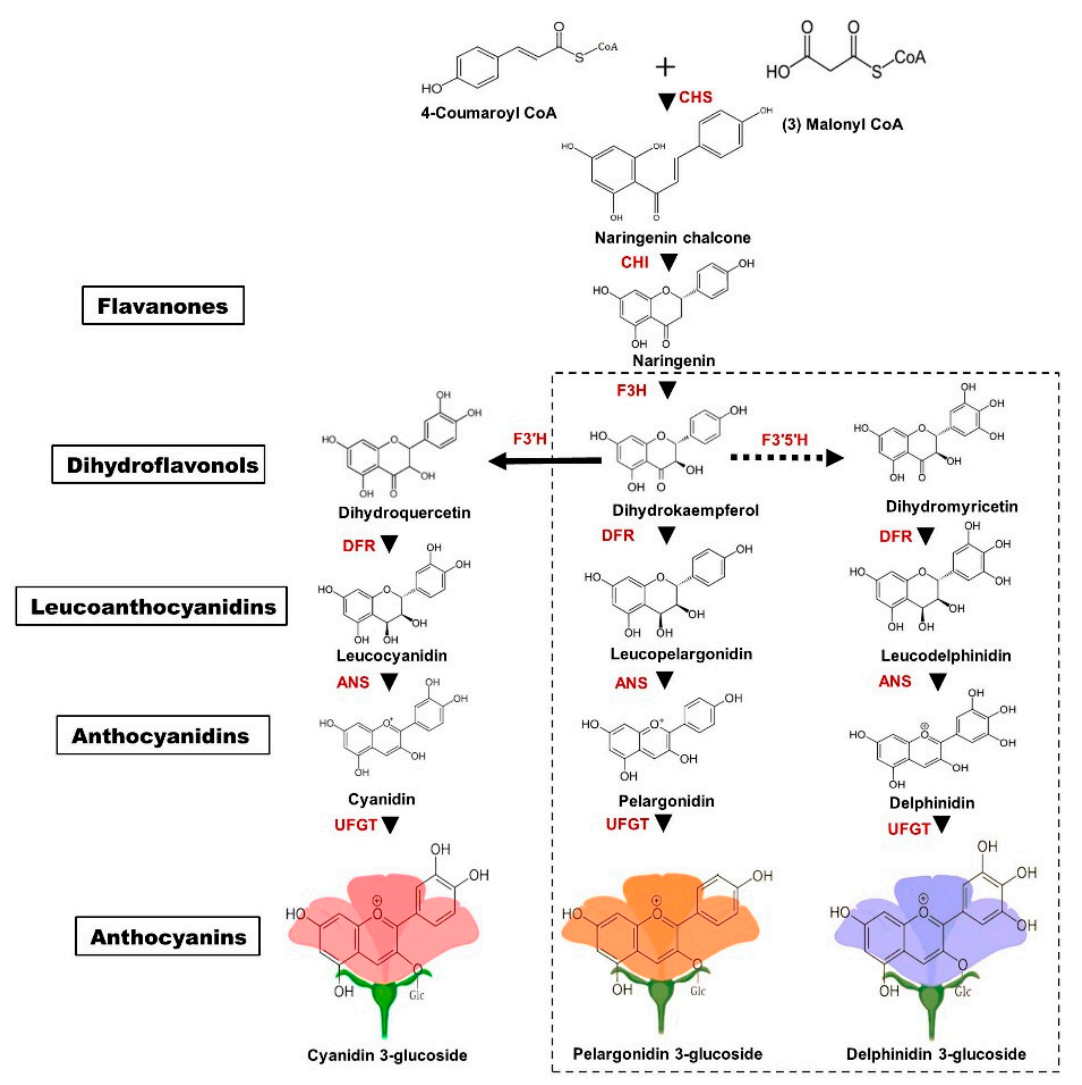

Figure 1. Schematic representation of the anthocyanin biosynthesis pathway. Enzymes involved in the biosynthesis pathway are shown in red. CHS—chalcone synthase; $\mathrm{CHI}-$ chalcone isomerase; F3H-flavanone 3-hydroxylase; F3' $\mathrm{H}$-flavonoid 3'-hydroxylase; F3' $5^{\prime} \mathrm{H}$-flavonoid $3^{\prime} 5^{\prime}$ - hydroxylase; DFR - dihydroflavonol 4-reductase; ANS — anthocyanidin synthase; UFGT_ UDP-glycosyl transferase. Chrysanthemum flowers only accumulate cyanidin-based anthocyanins; therefore, the cyanidin pathway is indicated by a solid arrow line. The dotted box indicates pelargonidin and delphinidin synthesis, which are naturally absent in chrysanthemum petals. The colored anthocyanin background represents the respective color attributed by that particular compound.

\section{Genes Involved in Anthocyanin Biosynthesis}

The pattern of petal pigmentation is determined by the expression levels of anthocyanin biosynthetic genes [41]. Mutations that arise either in the regulatory gene or in the biosynthetic gene, may interfere with the interaction between these genes [46]. Structural genes that have been reported to cause pigmentation in flowers include CHS, F3H, F3' $H, D F R$, and ANS. In chrysanthemum, seven structural genes, such as $C H S, F 3 H, F 3^{\prime} H, D F R, A N S, 3 G T$, and $3 M T$ have been identified as key genes responsible for anthocyanin biosynthesis, along with other transcription factors that are considered as major contributors [32,47]. $\mathrm{CmCHS}, \mathrm{CmCHI}$, and $\mathrm{CmF3}^{\prime} \mathrm{H}$ are highly expressed during early developmental stages, whereas, $\mathrm{CmF3H}, \mathrm{CmDFR}, \mathrm{CmANS}$, and CmUFGT are expressed in a coordinative manner throughout all stages of ray floret development [48]. The pattern of $\mathrm{CmCHI}$ expression was found to be similar among different cultivars with different anthocyanin contents $[49,50]$. The high expression levels of $C m D F R$ revealed a correlation between anthocyanin accumulation and pink- and white-colored chrysanthemum [32]. Similarly, 3GT expression was found to be markedly increased in pink flowered chrysanthemum cultivars, suggesting that it contributes to anthocyanin pigmentation [32]. Taken together, these results showed that the transcript levels of biosynthetic genes are consistent with anthocyanin biosynthesis in the ray florets of chrysanthemum. 


\section{Regulation of Anthocyanin Biosynthesis by Transcription Factors}

The regulatory mechanisms controlling anthocyanin biosynthesis have been well studied [51]. Members of three protein families, including R2R3MYB transcription factors (TFs), basic helix-loop-helix (bHLH) TFs, and WD40 Repeat Proteins (WDR) interact to form a ternary MBW complex, which subsequently regulates the expression of anthocyanin biosynthetic genes [51,52]. The R3 domain of R2R3 MYB interacts with the MIR region of bHLH, whereas the WDR interacts with a bHLH TF as a docking platform [53]. Other such interactions include AN2 (MYB) and AN1 (bHLH) in petunia flowers [54], MYB10 (MYB) and MYC1 (bHLH) in Gerbera hybrida flowers [55], and MYB12 and bHLH2 in lily flowers [56,57]. bHLH has a broad range of biological functions apart from anthocyanin biosynthesis and is therefore expressed in various other cell types where anthocyanins are not produced. However, R2R3 MYB TFs directly regulate the spatio-temporal expression of anthocyanin biosynthetic genes. MYB TFs determine the amount of anthocyanin produced by specific cells and hence, variation in the color intensity and pattern of the flower [34]. Recent studies reported that repressor genes, including R3MYBs such as AtMYBL2, and R2R3 MYB such as AtMYB44 and PhMYB27, negatively regulate anthocyanin biosynthesis by interfering with MBW complex formation [58,59].

The bHLH proteins belong to a superfamily of TFs containing a basic region with 15-17 amino acids required for DNA binding and a helix-loop-helix domain essential for the formation of homo and heterodimers [60]. A bHLH member was reported to be involved in the regulation of anthocyanin biosynthesis in Dahlia and Asiatic hybrid lily [56,61]. In Phalaenopsis, the endogenous bHLH member, interaction between PebHLH1-3 and PeMYBs was shown to be responsible for the pigmentation patterning in flowers [62]. Recently, Lim et al. (2017) revealed that RsTT8 functions in anthocyanin and proanthocyanidin biosynthesis through an interaction with RsMYB1 [63]. Based on clustering analysis, three CmMYBs and one CmbHLH were identified as candidate TFs for anthocyanin biosynthesis in chrysanthemum [47]. Liu et al. (2013) [64] found that endogenous bHLH proteins in conjunction with MYB1 are involved in anthocyanin biosynthesis. Based on this, further studies showed that the level of $\mathrm{CmbHLH} 2$ was positively correlated with anthocyanin content in the various colored flowers of chrysanthemum. In a simultaneous expression assay with $C m M Y B 6, C m b H L H 2$ significantly upregulated the CmDFR promoter and triggered anthocyanin biosynthesis, suggesting that $\mathrm{CmbHLH} 2$ is crucial for anthocyanin biosynthesis in chrysanthemum [65]. A representative model depicting the regulatory mechanism by TFs in chrysanthemum is shown in Figure 2A. 

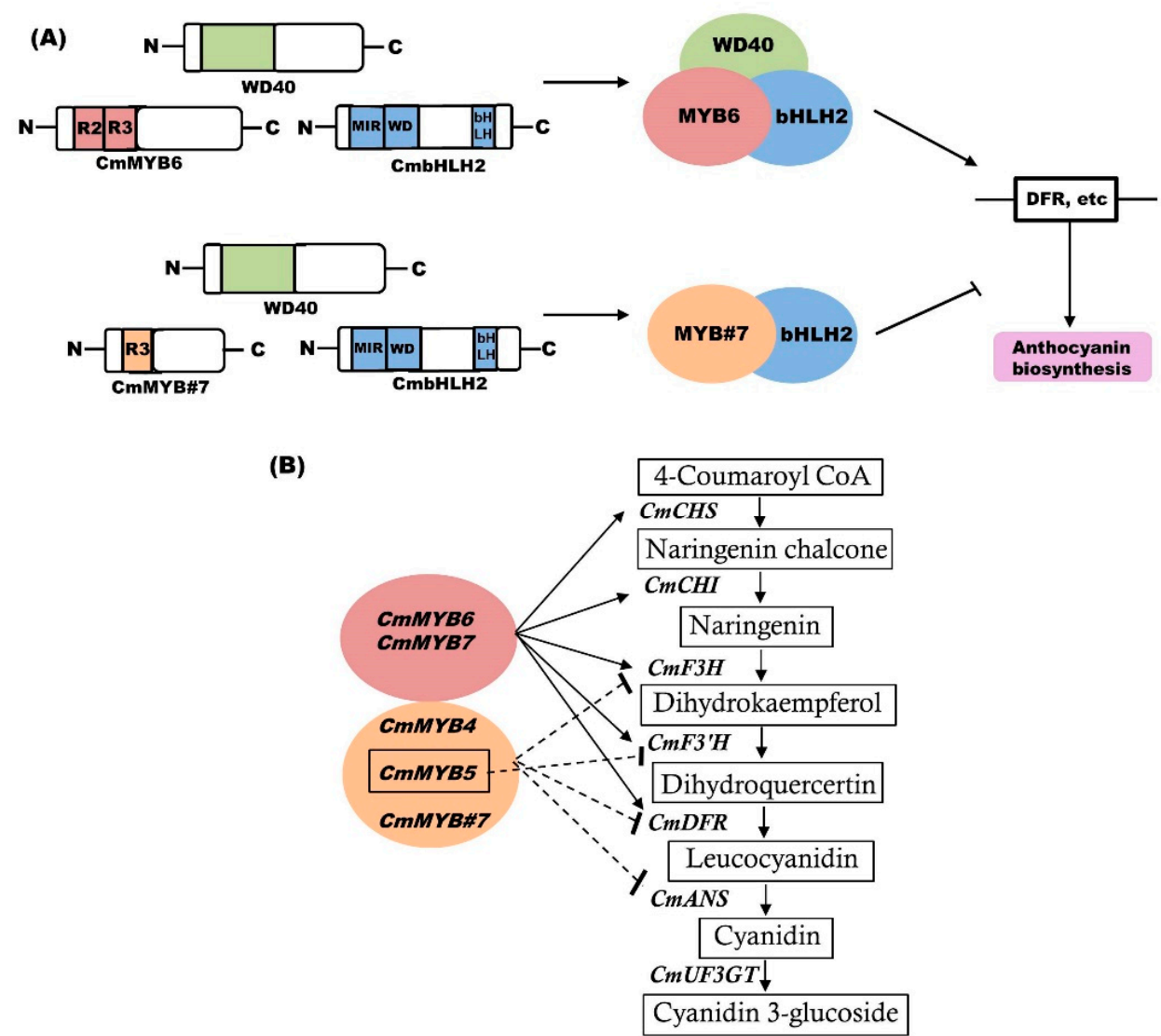

Figure 2. MYB-bHLH-WD40 (MBW) complex for the regulation of anthocyanin biosynthesis. (A) Schematic model to depict the regulatory mechanism of the MBW complex. bHLH proteins interacts with MYB transcription factors (TFs) and WD40 to form a ternary complex, thereby regulating structural genes. (i) Activation of anthocyanin biosynthesis regulation by MYB-activators. (ii) Repression of anthocyanin biosynthesis by MYB-repressors, which compete with MYB-activators for bHLH. Arrows $\left({ }^{\prime} \rightarrow\right.$ ') indicate activation, and blocked lines (' $-l^{\prime}$ ) indicate repression. (B) Representative MYBs for the regulation of anthocyanin biosynthesis. $C m M Y B 6$ and $C m M Y B 7$ are positive regulators of anthocyanin biosynthesis. In contrast, $C m M Y B 4, C m M Y B 5$, and $C m M Y B \# 7$ are repressors of anthocyanin biosynthesis. The arrow indicates activation and the dotted blocked arrow indicates repression (modified from [66].

MYB proteins represent a TF family in plants. The N-terminal domain of MYB is essential for DNA binding, while the C-terminal domain is involved in the regulatory activity of the protein [67]. MYBs are the most specific and crucial regulators of anthocyanin biosynthesis among the MBW complex [68]. Role of MYBs has been reported in various plants, including GMYB10 from Gerbera hybrida, LhMYB12-Lat from Asiatic hybrid lily, and PhAN2 from Petunia hybrida [69-71]. In chrysanthemum, three candidate CmMYBs for anthocyanin biosynthesis have been identified by cluster analysis [47]. Liu et al. (2015) identified four MYBs, including CmMYB3, CmMYB4, CmMYB5, and CmMYB6 from chrysanthemum 'Amadea' [72]. Among those, the expression of CmMYB3 and CmMYB6 was correlated with anthocyanin accumulation. Additionally, $C m M Y B 6$ alone activated the $C m D F R$ gene and induced anthocyanin biosynthesis in tobacco leaves when transiently co-expressed with a previously characterized anthocyanin regulator, MrbHLH1 [72]. Transgenic chrysanthemum expressing RsMYB1 presented enhanced accumulation due to the upregulation of $\mathrm{CmF3H}, \mathrm{CmDFR}$, and CmANS [73]. Recently, R3 MYB, CmMYB\#7 was identified as a passive repressor of anthocyanin biosynthesis [74]. $C m M Y B \# 7$ competes with $C m M Y B 6$ for the interaction with $C m b H L H 2$, and inhibits the active MBW complex, resulting in the suppression of structural gene expression [66]. Hong et al. (2019) showed that $C m M Y B 6$ and $C m M Y B 7$ positively regulate anthocyanin biosynthesis genes, whereas $C m M Y B 4$ and $C m M Y B 5$ are negative regulators [66]. It has been hypothesized that the control of $\mathrm{CmCHS}$, 
$\mathrm{CmCHI}, \mathrm{CmF3H}, \mathrm{CmDFR}$, and CmANS is coordinated by multiple regulators, whereas $\mathrm{CmF3}^{\prime} \mathrm{H}$ might be solely regulated by other TFs, such as CmMYB5 [66]. The results of Xiang et al. suggested that four CmMYBs might interact with bHLH TF(s) and consequently activate or repress the transcript levels of anthocyanin biosynthetic genes [74]. However, it is unclear whether these four CmMYBs interact with the same bHLH proteins as CmMYB\#7 (Figure 2B). Hence, protein-protein interaction studies among these CmMYBs, and CmbHLH2 [74] and CmbHLH24 [47] will provide insight into the mechanisms of anthocyanin biosynthesis in chrysanthemum.

\section{External Factors Regulating Anthocyanin Biosynthesis and Accumulation}

Anthocyanin biosynthesis is predominantly influenced by various physical and chemical factors. Therefore, this section discusses regulatory factors that have been reported to influence anthocyanin biosynthesis and thus, floral color.

\subsection{Physical Factors}

Various physical factors, such as temperature, light intensity and quality, water content, nutrients, and minerals have been identified to have a major influence on the accumulation of anthocyanin content in flower petals.

\subsubsection{Light Intensity and Quality}

Light intensity is one of the key factors that can influence anthocyanin biosynthesis [75]. Early studies demonstrated the light-induced accumulation of anthocyanins in various plants, such as Arabidopsis and Petunia hybrida [76,77]. Furthermore, the absence of light or weak light intensity is likely to suppress the expression of anthocyanin biosynthetic genes, resulting in a significant decrease in anthocyanin content in the flowers of various plants [78-80]. In chrysanthemum petals, shading was found to result in a significant decrease in anthocyanin accumulation, resulting in an almost white-colored flower [81]. Hong et al. reported that capitulum and foliage are the key organs that respond to light for anthocyanin accumulation in chrysanthemum flowers [81]. Recently, an in-depth review of molecular studies on chrysanthemum ray petals noted that transcriptional activators, such as MYB5-1, MYB6, MYB7-1, HY5, COP1, and bHLH24, are key genes involved in the light-induced accumulation of anthocyanin, in addition to anthocyanin biosynthetic genes in chrysanthemum ray petals [8]. More recently, a transcriptome analysis of C. morifolium 'Jinbeidahong' under short day (SD) and natural day (ND) light conditions, in which floral color was lighter under SD compared to ND, found that anthocyanin biosynthesis was tightly regulated by photo-period. The HY5-1, HY5-2, HY5-3, HY5-4, CHI1, and 3GT1 genes plays a significant role in the induction of anthocyanin biosynthesis under photo-periodic lighting [82].

The importance of light quality in the regulation of anthocyanin accumulation in flowers has been described in various plants, including petunia and rose $[83,84]$. Early findings showed that petunia has three photoreceptors that are involved in the regulation of anthocyanin synthesis [80]. In Arabidopsis, dihydroflavonol 4-reductase (DFR) is induced by red light, and chalcone synthase (CHS) is induced by blue light, whereas in gerbera, blue light is more effective at inducing anthocyanin accumulation [78,79]. A study by Ouzounis and co-authors showed that an increased blue light component induced flavonoid synthesis in chrysanthemum [84]. The levels of total flavonoids were found to be higher under white light in chrysanthemum leaves [85].

\subsubsection{Temperature}

Temperature is another physical factor that influences the expression of floral color in ray petals. Higher temperature was shown to cause a significant reduction in anthocyanin accumulation in various flowers, including lily [86], rose [87], petunia [88], and carnation [89], suggesting that higher temperature poses a major problem for floral color during the summer season in temperate regions and throughout the year in tropical zones. In particular, poor pigmentation has been observed at higher 
temperatures $\left(30^{\circ} \mathrm{C}\right)$ in different genotypes of chrysanthemum [90]. Additionally, the degree of color variation was found to differ among chrysanthemum genotypes at $30^{\circ} \mathrm{C}$, although no color change occurred in some genotypes. Studies by Nozaki et al. and Huh et al. reported that the pale pigmentation in pink-flowered genotypes of chrysanthemum was mainly due to a reduction of two anthocyanins (Cy 3-6"-MMG and Cy 3-3", 6" -DMG) under high temperature [91,92]. The total anthocyanin content was found to be considerably higher at $20^{\circ} \mathrm{C}$ compared with $30^{\circ} \mathrm{C}$ in chrysanthemum petals [93]. Expression of anthocyanin biosynthesis-related genes, including CHS1, CHS2, CHI, F3H2, C3' H, DFR1, $D F R 2$, and ANS was downregulated in ray petals when the plants were exposed to $30^{\circ} \mathrm{C}$.

\subsection{Chemical Factors}

Several reports had detailed the influence of environmental $\mathrm{pH}$ on the color intensity and pigmentation of flower petals $[94,95]$. Various studies have also shown that acidic $\mathrm{pH}$ has a positive effect on anthocyanin accumulation in rose and petunia [94,96]. An interesting study by Zaho and co-authors reported that the $\mathrm{pH}$ of petals was highly influenced by the $\mathrm{pH}$ of irrigated water in herbaceous peony [97]. Briefly, at $\mathrm{pH} 4.0$, the $\mathrm{pH}$ of petals increased and the anthocyanin content reduced significantly, and herbaceous peony exhibited a lighter floral color. Increased expression of the pH-regulating gene vacuolar $\mathrm{Na}^{+} / \mathrm{H}^{+}$antiporter 1 (NHX1), and decreased expression of the anthocyanin biosynthesis DFR gene, have been shown to be responsible for the reduced color in peony [97]. Furthermore, in chrysanthemum, vacuolar $\mathrm{pH}$ is a key factor that modulates the biosynthesis and quantity of anthocyanin pigments. The development of blue color in flowers has been well studied, and one of the mechanisms that achieves this is the modification of vacuolar $\mathrm{pH}[98,99]$. Blue-colored ray florets of transgenic chrysanthemum generated by expressing the anthocyanin, delphinidin 3-O(6' $6^{\prime \prime}-O$-malonyl) glucoside-3', $5^{\prime}$-di-O-glucoside presented a violet color under mildly acidic $\mathrm{pH}$ and a blue color only under co-pigmentation with other flavone glucosides in planta [40]. Recently, Rusishvili et al. combined computer simulations and photo absorption experiments of cyanidin-3-O-glucoside in water solution and elucidated the molecular mechanisms of color expression in anthocyanins within the $\mathrm{pH}$ range of 1-9 [100]. This study demonstrated that, in addition to the charge state of the molecule, $\mathrm{pH}$ also affects internal distortions in the chromophore, which influence their degree of conjugation, modulating the optical gap, and thus, the color.

Numerous studies have investigated the effects of plant hormones on the determination of floral color. For example, the transportation of gibberellins from the anther to the petal were reported to significantly upregulate the expression of anthocyanin biosynthesis genes [101]. Growth retardants can efficiently alter flower color. Application of prohexadione-calcium (Pro-Ca) changed the floral color from red to pale pink to white color in China rose [102]. Another study on daminozide, a chemical inhibitor of gibberellin biosynthesis, reduced floral coloration [103]. Menhenett et al. observed that the application of daminozide on dark pink chrysanthemum cultivar abrogated pigment production [104]. Subsequently, the potential underlying biochemical catalysis of daminozide revealed that the loss of red pigmentation in the ray petals of chrysanthemum was highly correlated with enzymatic inhibition of anthocyanidin synthase, resulting in reduced anthocyanidin content [105].

In addition to the above, anthocyanin content and accumulation are also affected by various other factors. For example, prolonged water stress caused flowers to darken in oriental hybrid lily [86], whereas in the leaves of Chrysanthemum morifolium cultivars, anthocyanin content increased with increasing water stress [106]. Gamma irradiation [107] and ion beam radiation [108] were found to influence anthocyanin accumulation in chrysanthemum flowers. Recently, Ryu et al. conducted a comparative study in Gamma-irradiated mutant Chrysanthemum morifolium cultivars and observed that the mutant cultivars producing purple to pink ray petals, accumulated higher amounts of anthocyanins compared with original cultivars [109]. Conversely, mineral nutrients are widely known to regulate floral color. Phosphorous deficiency has been associated with the increased synthesis of anthocyanins and is responsible for a darker coloration [110]. This may be because phosphorous deficiency reduces the synthesis of carbohydrates, resulting in an increased amount of soluble sugars 
and anthocyanins [111]. The presence of potassium has a favorable effect on floral color [112]. However, the effect of the same potassium differs among various colored varieties. Spraying potassium was shown to improve the floral color of orange and red varieties, but did not affect yellow varieties in lily. The mechanism underlying the change in pigmentation remains unclear [113].

\section{Breeding for Anthocyanins}

Plant breeding is the purposeful manipulation of plant species to develop desired phenotypes and genotypes with specific traits. Several breeding strategies have been employed for floral color, floral shape, plant architecture, disease resistance, and stress tolerance. Various tools are used to improve plant traits, including cross breeding, mutational breeding, and breeding by genetic modification. A large number of cultivars have been developed through cross-breeding and mutational breeding, which apply to a limited number of traits. Additionally, transgenic technologies have been applied to a variety of ornamental plants to improve desired traits by engineering the genomes [114]. The most fascinating blue-colored flowers in roses and chrysanthemums were made possible by the use of powerful transgenic technology in combination with genetic and biochemical analyses. This would not have been possible using conventional breeding techniques, especially in roses and chrysanthemums as they lack the delphinidin pathway $[40,45]$. Methods of breeding that are employed to modify floral color are discussed in the following sections.

\subsection{Crossbreeding}

Crossbreeding is a powerful classical tool that has been practiced for decades to generate attractive cultivars, with new traits in the majority of crops. As chrysanthemums are highly heterozygous, conventional crossbreeding between two parents possessing contrasting traits remains the most effective way of breeding new cultivars [5]. As genetic differences in parents and hybrid performance are positively correlated, the selection of parents with genetic variation is a key factor for successful breeding [115]. Intra- and inter-specific hybridization have been used in chrysanthemum for many traits, including plant type [116], stress resistance [117], and flowering time [116,118]. Numerous cultivars have been developed by crossbreeding for floral color in chrysanthemum. For example, an inter-specific cross between hexaploid C. weyrichii (Maxim.) Tzvelv. and C. grandiflora Tzvelv. resulted in a new garden chrysanthemum cultivar 'Lavender Daisy' with a new floral color for the Mammoth series, exhibiting dark purple ray florets and golden disc florets [119]. Mammoth 'Dark Bronze Daisy', with novel dark bronze daisy flowers and gold disk florets, was developed by an inter-specific cross between C. weyrichii (Maxim.) Miyabe 'Pink Bomb' $\times$ C. grandiflorum Tzvelv. 'Adorn' [120].

In a recent study, inter-specific crossability of transgenic blue chrysanthemum developed by Noda et al. [40] with the wild species Chrysanthemum japonense var. japonense was checked [121]. This study demonstrated the heritability of the transgene and confirmed the transmission of the transgene to interspecific progeny. Furthermore, the progeny also accumulated anthocyanins that were specific to the parent plant. This provides basic information that may be used to prevent transgene flow to native chrysanthemum species in order to commercialize the blue-hued varieties [121]. Intriguingly, our work on the breeding of new chrysanthemum cultivars for novel floral colors using inter- and intra-specific breeding has resulted in a large number of cultivars exhibiting alluring flower hues. Flower images of some of the chrysanthemum cultivars developed from our work are shown in Figure 3A [122,123]. 
(A)
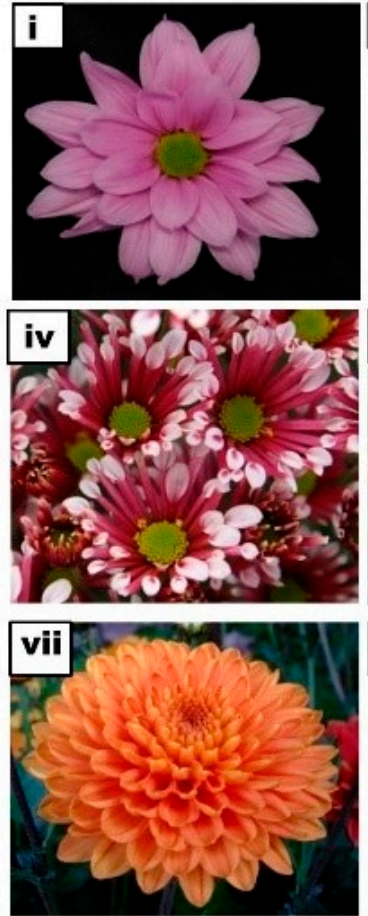
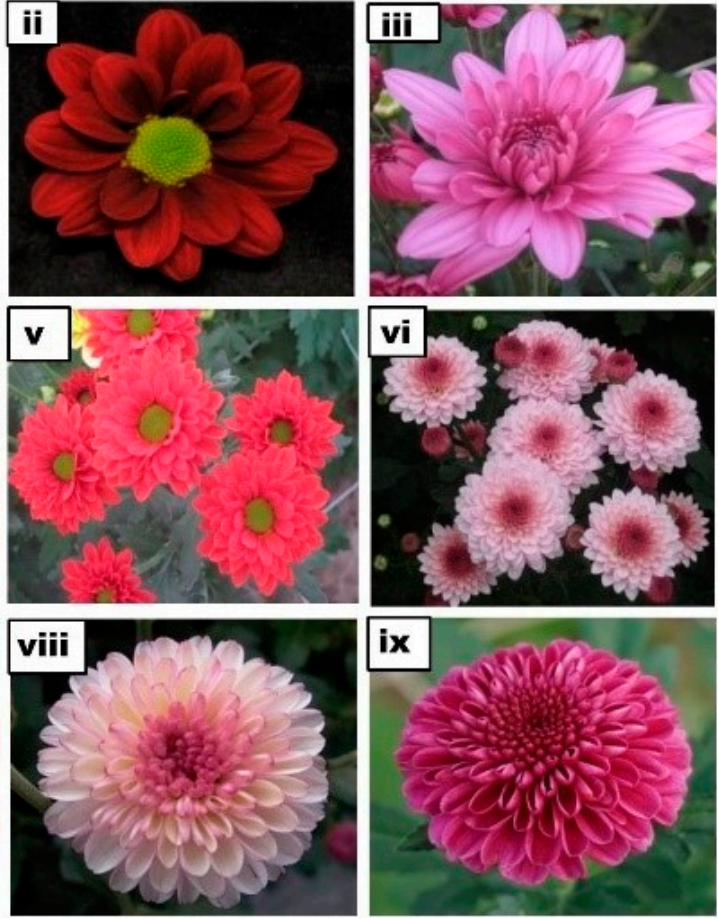

(B)
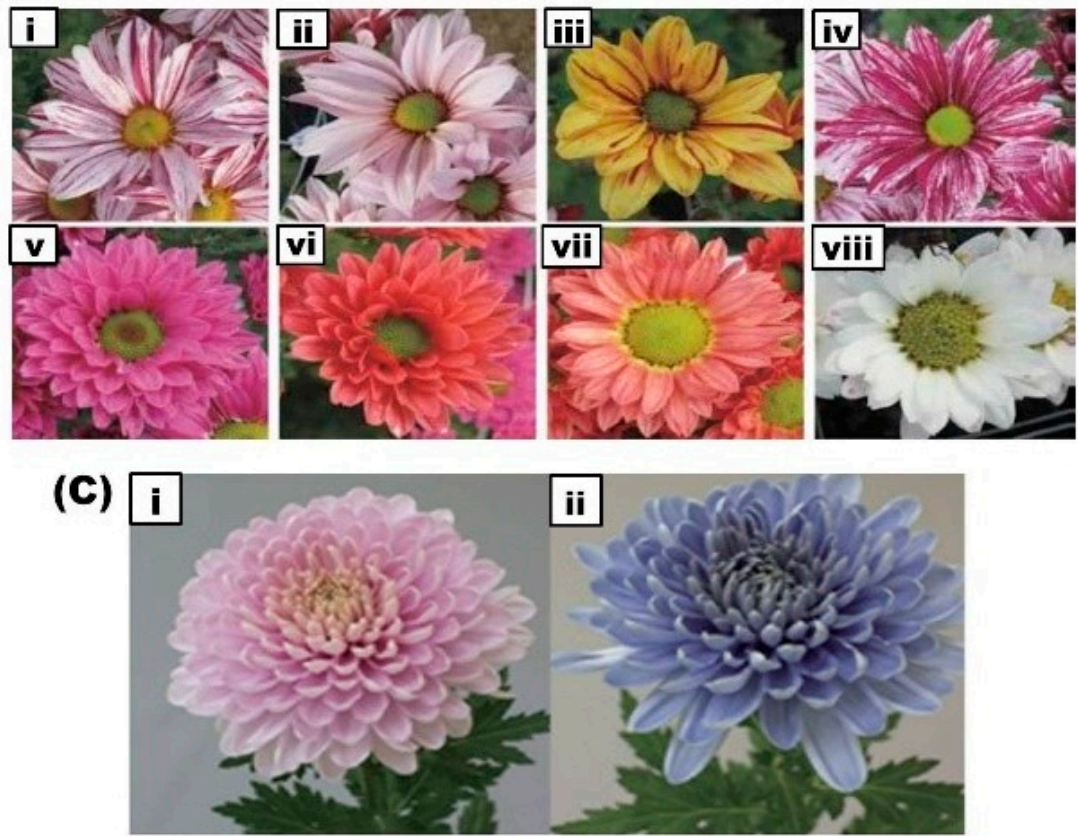

Figure 3. Representative images showing the modification of floral color in chrysanthemum by various breeding methods. (A) Diverse and vibrant colored flowers expressing anthocyanins in chrysanthemum cultivars developed by our work through cross breeding at (National Institute of Horticultural and Herbal Sciences (NIHHS), RDA, Korea. (i): Glory pink; (ii): Red marble; (iii): Donna pink; (iv): Purple cone; (v): Princeling; (vi): Cutie pink; (vii): Orange pangpang; (viii): Pink pangpang: and (ix): Purple pangpang. (B) Modification of floral color by mutation breeding. A range of floral colored mutants presenting various colors were generated by gamma-irradiation in two chrysanthemum cultivars 'Noble wine' and 'Pinky'. (i): Original floral color of 'Noble wine'; (ii-iv): gamma-irradiated mutants of 'Noble wine' showing varied floral colors. (v): Original floral color of 'Pinky'; and (vi-viii): gamma-irradiated mutant floral colors of 'Pinky' [107]. (C) Generation of blue-colored chrysanthemum flowers by metabolic engineering. (i): wild-type red-purple colored flower; (ii): transgenic blue-colored flower generated in combination with the overexpression of CamF3'5'H and CtUGT, and co-pigmentation [40]. 


\subsection{Molecular Breeding}

Floral color is one of the most widely studied traits at the genetic level, and various studies have characterized the mutations responsible for floral color variations in plants [124]. Studies have revealed that variations in floral color involve the common genetic route, which indicates optimal methods to modify floral color [125]. To date, the chrysanthemum breeding program has resulted in the development of various cultivars. However, further advances in conventional morphology-based selection are needed for molecular marker-assisted breeding. These molecular breeding studies require the identification of trait-linked molecular markers from genetic, molecular, and genomic studies. However, the reproductive, genomic, and genetic makeup of chrysanthemum, including self-incompatibility, inbreeding depression, allohexaploid, heterozygosity, genome duplications, and large genome size, significantly hinder these studies. Molecular breeding, popularly known as marker-assisted selection (MAS), enables the identification of markers associated with plant traits, which also indirectly select the phenotype of the plant. The linkage map facilitates the identification of genomic regions associated with the desirable traits, thereby providing a base for MAS-breeding. Furthermore, quantitative trait loci (QTL) mapping identifies the genes that control a trait based on linkage mapping [126]. However, MAS-breeding in polyploids, such as chrysanthemum, is progressing at a slower pace due to various technical and scientific limitations [127]. This is because the linkage mapping and QTL analysis for DNA marker development require specialized statistical methods in order to estimate recombination frequency and achieve QTL detection [128]. Nevertheless, numerous genetic studies have successfully constructed genetic linkage maps and identified molecular markers, including amplified fragment length polymorphism (AFLP), random amplified polymorphic DNA (RAPD), sequence-related amplified polymorphism (SRAP), simple sequence repeat (SSR) markers, and single-nucleotide polymorphism (SNP) markers associated with important plant and flower traits in chrysanthemum [129]. Advances in sequencing technologies have provided whole genome sequence information for the diploid wild chrysanthemum species, Chrysanthemum nankingense [130] and Chrysanthemum seticuspe [131]. This contributes to further studies exploring the connection between genotype and phenotype, and will help to overcome some of the barriers for molecular breeding in chrysanthemum. QTL detection in chrysanthemum has been achieved using sophisticated methods to handle its genome complexity. Van Geest et al. reported the first integrated ultra-dense linkage map in a hexaploid species with polysomic inheritance in chrysanthemum, which identified some of the QTLs for floral color along with other floral traits, such as flowering time, ray floret number, and disc florets de-greening [132]. Two regions, CLG5 and 7, were found to be significantly associated with floral color and one region, CLG9, was slightly associated with floral color. Analysis of variance of the interaction between the associated alleles identified a highly significant interaction, suggesting that both alleles are required to obtain pink-colored flowers [132]. This study represented a breakthrough for further linkage analyses in chrysanthemum. Genome-wide association studies (GWAS) are an effective tool that connects the phenotype and genotype based on the available linkage disequilibrium [133]. In chrysanthemum, considerable progress has been made in recent years to identify favorable alleles by GWAS for traits such as waterlogging tolerance [134], aphid resistance [135], drought tolerance [136], plant architecture traits, and inflorescence traits [137] based on SRAP, start codon-targeted (SCoT), and SSR marker loci. Chong et al. first reported a GWAS for four floral traits of floral color, floral shape, ray floret type, and cultivated type, and identified seven SNPs within six genes that are predictive of only floral shape, ray floret type, and cultivated type [138]. However, these SNPs did not show any association with floral color. Shumitomo and co-authors reported the first simple GWAS-based marker developing system in autohexaploid species, such as chrysanthemum [128]. Their study aimed to verify whether DNA markers for carotenoid pigmentation, which determines ray petal color, could be effectively developed using GWAS in autohexaploid chrysanthemum. Because carotenoid pigmentation in the petal is controlled by the dominant allele of the inhibitor, and a casual gene $\mathrm{CmCCD} 4 a$ is responsible for carotenoid cleavage in ray petals, a parent 'Ariesu' was identified as duplex for the carotenoid cleavage allele. Hence, SNP markers developed for each allele have demonstrated 
a perfect association with carotenoid cleavage in ray petals and with the absence or presence of the genes $C m C C D 4 a-1$ and $C m C C D 4 a-5$ in the F1 population, indicating the effectiveness of GWAS method. Together, these studies represent ground-breaking advances towards the integration of phenotypic and genotypic information, and for further advancement in the breeding of chrysanthemum for desirable traits like floral color.

\subsection{Mutation Breeding}

Although crossbreeding is a powerful tool for the development of cultivars, it is quite complicated in heterologous ornamental plants. In this case, mutation breeding is suitable for modifying a few traits in an elite cultivar without affecting the existing traits. This method is highly efficient for creating sterile interspecific hybrids [139], native ornamentals with a limited gene pool in given species [140], and plants with longer juvenile periods [141]. Usually, ultraviolet light, chemical mutagens, and ionizing radiation, such as X-rays and gamma rays, are used to induce a wide spectrum of mutations in ornamental plants. This induced mutagenesis is an established method and has been successfully exploited for the development of diverse novel ornamental varieties in various crops. The induction of mutations in the biosynthetic pathways of structural and regulatory genes has resulted in changes in floral color in various plants, including Phalaenopsis and Gentian plants [142-144]. Mutations in the early steps of the anthocyanin biosynthesis pathway result in white flowers, whereas mutations in the later parts of the pathway lead to the generation of different colored flowers due to the accumulation of particular anthocyanins [145]. Recently, heavy-ion or ion beams have been used to generate new varieties in carnation, rose, and chrysanthemum [146]. Mutation breeding has been successfully employed for decades in chrysanthemum to develop novel floral colors using X-ray irradiation [147,148] and gamma irradiation [149-151] through the modification of the anthocyanin biosynthesis pathway (Figure 3B). For example, six mutant varieties have been generated by ion-beam radiation in chrysanthemum for different variations in floral color, including a complex with light yellow and pink; a complex with light yellow and light pink; a complex with light pink and yellowish-orange; a complex with light pink and bright orange-yellow; and a variation with light orange on the adaxial side and dark yellow-orange on the abaxial side [152]. There are some major limitations to mutation breeding; for example, these mutations are not programmable to specific locations, and the chimeric status of each cell possesses different mutations. However, a combination of irradiation and tissue culture is used to resolve the chimeras in chrysanthemum [153].

\subsection{Genome Editing}

Genome editing enables the induction of mutations in a targeted genomic region and has played a substantial role in plant functional genomics and biotechnology [114]. Due to the generation of precise mutations in the targeted sequence, it is considered to be more effective than conventional mutation breeding. This breakthrough technology has been adopted for various crops [124]. Unlike transgenic technology, genome editing does not require the transgene to be integrated with the genome, and hence an integrated transgene could be segregated in the progeny. The clustered regularly interspaced short palindromic repeats (CRISPR)-associated protein 9 (Cas9) system, is the most widely used genome editing system [154]. Cas9 is a nuclease that can cleave the double-stranded DNA of the target sequence, and insertion/deletion mutations of variable length can be introduced into the target sequence during the repair of the Cas9-induced double-stranded breaks [114].

Application of the CRISPR-Cas9 system to ornamental plants has been limited due to a lack of whole genome information to identify the target sequence and transformation system. To date, only a few successful genome-edited ornamental plants on floral traits have been reported. Petunia has been edited with CRISPR-Cas9 targeting various traits, including an albino phenotype [155], flower longevity [156], deficiency in nitrate assimilation [157], and self-incompatibility [158]. The LpPDS gene in two Lilium species was successfully edited resulting in albino, pale yellow, and albino-green chimeric mutants [159]. Multiple MADS genes have been targeted in Phalaenopsis for flower initiation 
and development [160]. CRISPR-Cas9 has been applied to various ornamental plants for floral color. The flavonoid biosynthesis gene $\left(F 3^{\prime} H\right)$ was edited in Torenia fournieri, presenting a pale blue floral color [161]. A knock-out mutant of the CCD4 gene was generated through genome editing, which harbored the ability to degrade carotenoid, and presented a yellow pigment due to its accumulation in both Japanese morning glory and Ipomoea nil $[162,163]$. However, the generation of genome-edited plants with a simultaneous mutation in polyploid plants is complicated, because the double-strand break and repair events occur at each target site independently. Hence, the higher the number of target sites, the lower the probability of mutation in these plants [114]. Whole-genome information is not yet available for chrysanthemum due to its large genome and hexaploidy. However, Kishi-Kaboshi et al. first reported that disruption of fluorescence protein in chrysanthemum resulted in decreased fluorescence in flowers [114]. A transgenic chrysanthemum carrying the yellowish-green fluorescent protein (CPYGFP) gene was used for genome editing and was mutated by two sgRNAs targeted CPYGFP at different positions. The resultant CRISPR-CpYGFP-edited flowers presented decreased fluorescence compared to the normal CPYGFP flowers [114]. Hence, this result provides a basis and scope for further trials of genome editing in complex polyploid chrysanthemum plants. A limitation of genome editing in vegetatively propagated polyploid plants such as chrysanthemum and potato that cannot segregate the transgene, is that it is not feasible to introduce simultaneous mutations without transgene integration. However, CRISPR-Cas9 genome editing remains a revolutionary and promising technology for crop breeding in chrysanthemum for beneficial traits such as floral color.

\subsection{Transgenics for the Modification of Anthocyanin Accumulation}

In addition to classical breeding, metabolic engineering of anthocyanins is used to develop commercially desirable floral colors. Two strategies are employed to modify floral color. One approach is to overexpress the gene at the rate-limiting step or to block a gene in the competitive pathway. The second approach is to use TFs to alter anthocyanin accumulation [164]. Genetic modifications have been successfully applied to change the floral color in various plants, including rose and carnation $[45,165]$. Kee et al. developed a transgenic chrysanthemum overexpressing RsMYB1, in which the expression of three anthocyanin biosynthetic genes, such as $F 3 H, D F R$, and ANS, was elevated. However, there was no visual enhancement of anthocyanin in the transgenic plants [73]. Members of the family Asteraceae, such as cineraria and African daisy, can accumulate delphinidin-based anthocyanins in their flowers due to the activity of $F 3^{\prime} 5^{\prime} H$ [166]. However, the Chrysanthemum genus in Asteraceae does not contain $F 3^{\prime} 5^{\prime} H$ activity and hence is unable to synthesize delphinidin-based anthocyanins. Therefore, it is difficult to obtain blue flowers by cross-breeding within the genus. Tanaka et al. reported that the genes encoding $\mathrm{F}^{\prime} 5^{\prime} \mathrm{H}$ exist in various plants, which serve as a powerful tool for delphinidin-based anthocyanin pigment accumulation [167]. To generate a blue flower in chrysanthemum, He et al. attempted to reconstruct the delphinidin pathway by overexpressing the $F 3^{\prime} 5^{\prime} H$ gene from Senecio cruentus and downregulating the $F 3^{\prime} H$ gene to block cyanidin synthesis. However, the transgenic chrysanthemum presented bright red petals due to the increased level of cyanidins [48]. Genetic engineering of delphinidin production was achieved via transformation with a chimeric pansy $F 3^{\prime} 5^{\prime} \mathrm{H}$ gene under the control of floral-specific promoters, resulting in violet/blue-colored petals in chrysanthemum flowers [168]. Similarly, delphinidin production was manipulated by combining a chrysanthemum $F 3 H$ promoter-driven alcohol dehydrogenase $(A D H)$ translational enhancer-fused Campanula $F 3^{\prime} 5^{\prime} H$, leading to the formation of blue/violet flowers in chrysanthemum [39]. Noda et al. (2017) successfully produced true blue-colored chrysanthemum flowers by introducing the butterfly pea uridine diphosphate (UDP)-glucose: anthocyanin $3^{\prime}, 5^{\prime}$-O-glucosyltransferase gene, in addition to expression of the Canterbury bells $F 3^{\prime} 5^{\prime} H$ gene [40] (Figure 3C). These studies have therefore established a powerful basis for the molecular breeding of delphinidin-producing chrysanthemums. 


\section{Absence of Floral Anthocyanins}

A lack of either anthocyanins or carotenoids usually produces white petals. However, the majority of white flowers contain a subgroup of flavonoids, such as flavonols and flavanones. Although flavonols and flavanones are colorless pigments, the petals that accumulate a significant amount of these pigments exhibit either a cream or ivory color [32]. A lack of these flavonoids results in the development of pure white petals in some cultivars of snapdragon and carnation $[169,170]$. In some chrysanthemum cultivars, anthocyanins could not be detected in the petals of white flowers [171]. An absence of anthocyanins occurs due to abrogation of the anthocyanin biosynthesis pathway, because of mutations in the biosynthesis genes or TFs in the pathway [8]. Expression of the biosynthetic genes DFR and 3GT was found to be significantly lower in white petals compared to pink petals in chrysanthemum cultivars [32]. The mechanism for the suppressed gene expression in white petals needs to be further elucidated.

\section{Conclusions and Future Prospects}

Floral color is a major breeding target, because it determines the commercial value of ornamental plants. Anthocyanins are the important pigments that can attribute the petal color in flowers. In nature, chrysanthemums accumulate cyanidin-based anthocyanins, and produce fair pinkish to red to purple colored flowers. Variation in the number of anthocyanins changes the intensity of floral color and shifts in the pigment composition or multiple pigment combinations alter the floral hue. Several physical and chemical factors, as well as genetic and transcriptional regulators, influence anthocyanin accumulation and petal color. Research on anthocyanin biosynthesis and accumulation has progressed substantially in chrysanthemum in recent years. Genes involved in the anthocyanin biosynthesis pathway and their expression profiles have been elucidated in chrysanthemum. These insights have enabled the successful development of blue-colored flowers in chrysanthemum, even though chrysanthemum lacks delphinidin-based anthocyanins in nature. Due to the importance of environmental and product safety, the future development of technology to prevent possible gene flow is essential for commercializing these transgenic chrysanthemums. Furthermore, studies on the upstream regulatory mechanisms that control anthocyanin accumulation are needed. Hence, an understanding of the genetic and molecular mechanisms that control the organ and cellular- specific accumulation of anthocyanins is required. The transcriptome [172,173] and genome [131] of chrysanthemum species provide a basis for the identification of genes of interest. Nevertheless, studies on the genetic mechanisms that control anthocyanin biosynthesis are challenging and are still lagging behind in chrysanthemum. Elucidating the genetic control of anthocyanin biosynthesis enables the development of molecular markers for these traits. Although MAS has been extensively developed in chrysanthemum, further development of a large number of molecular markers would provide a basis for determining the alleles of a particular gene, which would be a useful tool for breeders to achieve the desired color for the flower. This could be achieved by further research focusing on QTL mapping and GWAS, which can dissect the complex genetic control involved in regulating anthocyanin biosynthesis. Additionally, integration of multiple omics platforms and their application, which serve to identify candidate genes to improve and modify floral color, are still not adequate in chrysanthemum. Furthermore, genome editing by the revolutionary CRISPR/Cas9 tool has huge potential for the functional analysis of traits. In the future, this could represent a breakthrough technology to modify and achieve the target floral color. Overall, this review offers a reference for the promotion of breeding and genetic engineering for the development of novel and diverse hues in flowers.

Author Contributions: M.M. and B.M.K.V. drafted the manuscript; M.M., B.M.K.V., M.-S.A. collected the background information; O.-K.K., S.-H.L. and J.-A.J. critically revised the manuscript. All authors have read and agreed to the published version of the manuscript.

Funding: This work was financially supported by the Next Generation Bio-Green 21 Research Program (PJ01336002) and a grant from the National Institute of Horticultural and Herbal Science (PJ01098202), Rural Development Administration, Republic of Korea. 
Conflicts of Interest: The authors declare no conflict of interest.

\section{References}

1. Behe, B.; Nelson, R.; Barton, S.; Hall, C.; Safley, C.D.; Turner, S. Consumer preferences for Geranium flower color, leaf variegation, and price. HortScience 1999, 34, 740-742. [CrossRef]

2. Posadas, B.C.; Coker, C.H.; Knight, P.R.; Fain, G. Consumer survey of selected garden chrysanthemum cultivars in Mississippi. HortTechnology 2006, 16, 539-543. [CrossRef]

3. Yan, J.; Wang, G.; Sui, Y.; Wang, M.; Zhang, L. Pollinator responses to floral colour change, nectar and scent promote reproductive fitness in Quisqualis indica (Combretaceae). Sci. Rep. 2016, 6, 1-10. [CrossRef] [PubMed]

4. Samanta, A.; Das, G.; Das, S.K. Roles of flavonoids in plants. Carbon 2011, 100, $12-35$.

5. Teixeira da Silva, J.A.; Shinoyama, H.; Aida, R.; Matsushita, Y.; Raj, S.K.; Chen, F. Chrysanthemum Biotechnology: Quo vadis? Crit. Rev. Plant Sci. 2013, 32, 21-52. [CrossRef]

6. Hong, Y.; Bai, X.; Sun, W.; Jia, F. The numerical classification of chrysanthemum flower color phenotype. Acta Hortic. Sin. 2012, 39, 1330-1340.

7. Wijayani, A.; Muafi, M.; Sukwadi, R. Market actor's response towards flower colours in determining the economic value of Chrysanthemum flowers. J. Bus. Retail Manag. Res. 2017, 12, 69-75. [CrossRef]

8. Ohmiya, A. Molecular mechanisms underlying the diverse array of petal colors in chrysanthemum flowers. Breed. Sci. 2018, 68, 17075. [CrossRef]

9. Zhao, D.; Tao, J. Recent advances on the development and regulation of flower color in ornamental plants. Front. Plant Sci. 2015, 6, 261. [CrossRef]

10. Britton, G.; Liaaen-Jensen, S.; Pfander, H. Carotenoids: Handbook; Birkhäuser: Basel, Switzerland, 2012.

11. Cook, N.C.; Samman, S. Flavonoids—chemistry, metabolism, cardioprotective effects, and dietary sources. J. Nutr. Biochem. 1996, 7, 66-76. [CrossRef]

12. Nielsen, A.H.; Olsen, C.E.; Møller, B.L. Flavonoids in flowers of 16 Kalanchoe blossfeldiana varieties. Phytochemistry 2005, 66, 2829-2835. [CrossRef] [PubMed]

13. Kong, J.-M.; Chia, L.-S.; Goh, N.-K.; Chia, T.-F.; Brouillard, R. Analysis and biological activities of anthocyanins. Phytochemistry 2003, 64, 923-933. [CrossRef]

14. Gantait, S.S.; Pal, P. Anthocyanin content of spray Chrysanthemum cultivars under polyhouse and open field conditions. Indian J. Nat. Prod. Resour. 2010, 1, 236-242.

15. Meléndez-Ackerman, E.; Campbell, D.R.; Waser, N.M. Hummingbird behavior and mechanisms of selection on flower color in Ipomopsis. Ecology 1997, 78, 2532-2541. [CrossRef]

16. Riffell, J.A.; Lei, H.; Abrell, L.; Hildebrand, J.G. Neural basis of a pollinator's buffet: Olfactory specialization and learning in Manduca sexta. Science 2013, 339, 200-204. [CrossRef]

17. Nuttman, C.; Willmer, P. How does insect visitation trigger floral colour change? Ecol. Entomol. 2003, 28, 467-474. [CrossRef]

18. Pereira, A.C.; da Silva, J.B.; Goldenberg, R.; Melo, G.A.; Varassin, I.G. Flower color change accelerated by bee pollination in Tibouchina (Melastomataceae). Flora Morphol. Distrib. Funct. Ecol. Plants 2011, 206, 491-497. [CrossRef]

19. Briscoe, A.D.; Chittka, L. The evolution of color vision in insects. Annu. Rev. Entomol. 2001, 46, 471-510. [CrossRef]

20. Menzel, R.; Backhaus, W. Color vision in insects. In Vision and Visual Dysfunction. VI. Perception of Color; Macmillan Press: Houndmills, UK, 1991.

21. Chittka, L.; Shmida, A.; Troje, N.; Menzel, R. Ultraviolet as a component of flower reflections, and the colour perception of Hymenoptera. Vis. Res. 1994, 34, 1489-1508. [CrossRef]

22. Penny, J. Nectar guide colour contrast: A possible relationship with pollination strategy. New Phytol. 1983, 95, 707-721. [CrossRef]

23. Lunau, K.; Konzmann, S.; Winter, L.; Kamphausen, V.; Ren, Z.-X. Pollen and stamen mimicry: The alpine flora as a case study. Arthropod-Plant Interact. 2017, 11, 427-447. [CrossRef]

24. Bradshaw, H.; Schemske, D.W. Allele substitution at a flower colour locus produces a pollinator shift in monkeyflowers. Nature 2003, 426, 176-178. [CrossRef]

25. Chalker-Scott, L. Environmental significance of anthocyanins in plant stress responses. Photochem. Photobiol. 1999, 70, 1-9. [CrossRef] 
26. Kovinich, N.; Kayanja, G.; Chanoca, A.; Riedl, K.; Otegui, M.S.; Grotewold, E. Not all anthocyanins are born equal: Distinct patterns induced by stress in Arabidopsis. Planta 2014, 240, 931-940. [CrossRef] [PubMed]

27. Ai, T.N.; Naing, A.H.; Yun, B.-W.; Lim, S.H.; Kim, C.K. Overexpression of RsMYB1 enhances anthocyanin accumulation and heavy metal stress tolerance in transgenic petunia. Front. Plant Sci. 2018, 9, 1388. [CrossRef]

28. Naing, A.H.; Lee, D.B.; Ai, T.N.; Lim, K.B.; Kim, C.K. Enhancement of low pH stress tolerance in anthocyanin-enriched transgenic petunia overexpressing RsMYB1 gene. Front. Plant Sci. 2018, 9, 1124. [CrossRef]

29. Shan, H.; Chen, S.; Jiang, J.; Chen, F.; Chen, Y.; Gu, C.; Li, P.; Song, A.; Zhu, X.; Gao, H. Heterologous expression of the chrysanthemum R2R3-MYB transcription factor CmMYB2 enhances drought and salinity tolerance, increases hypersensitivity to ABA and delays flowering in Arabidopsis thaliana. Mol. Biotechnol. 2012, 51, 160-173. [CrossRef]

30. Grotewold, E. The Science of Flavonoids; Springer: Berlin/Heidelberg, Germany, 2006.

31. Li, M.; Chen, J.; Sun, Z.; Chen, Y.; Li, H. Advances in molecular breeding of ornamental plants. J. Trop. Subtrop. Bot. 2003, 11, 87-92.

32. Chen, S.-M.; Li, C.-H.; Zhu, X.-R.; Deng, Y.-M.; Sun, W.; Wang, L.-S.; Chen, F.-D.; Zhang, Z. The identification of flavonoids and the expression of genes of anthocyanin biosynthesis in the chrysanthemum flowers. Biol. Plant. 2012, 56, 458-464. [CrossRef]

33. Tanaka, Y.; Sasaki, N.; Ohmiya, A. Biosynthesis of plant pigments: Anthocyanins, betalains and carotenoids. Plant J. 2008, 54, 733-749. [CrossRef]

34. Zhang, Y.; Butelli, E.; Martin, C. Engineering anthocyanin biosynthesis in plants. Curr. Opin. Plant Biol. 2014, 19, 81-90. [CrossRef] [PubMed]

35. Sun, W.; Li, C.; Wang, L.; Dai, S. Analysis of anthocyanins and flavones in different-colored flowers of chrysanthemum. Chin. Bull. Bot. 2010, 45, 327-336.

36. Nakayama, M.; Koshioka, M.; Shibata, M.; Hiradate, S.; Sugie, H.; Yamaguchi, M.-A. Identification of cyanidin 3-O-(3", 6+"-O-dimalonyl- $\beta$-glucopyranoside) as a flower pigment of Chrysanthemum (Dendranthema grandiflorum). Biosci. Biotechnol. Biochem. 1997, 61, 1607-1608. [CrossRef]

37. Saito, N.; Toki, K.; Honda, T.; Kawase, K. Cyanidin 3-malonylglucuronylglucoside in Bellis and cyanidin 3-malonylglucoside in Dendranthema. Phytochemistry 1988, 27, 2963-2966. [CrossRef]

38. Kawase, K.; Tsukamoto, Y. Studies on flower color in Chrysanthemum morifolium Ramat. J. Jpn. Soc. Hortic. Sci. 1976, 45, 65-75. [CrossRef]

39. Noda, N.; Aida, R.; Kishimoto, S.; Ishiguro, K.; Fukuchi-Mizutani, M.; Tanaka, Y.; Ohmiya, A. Genetic engineering of novel bluer-colored chrysanthemums produced by accumulation of delphinidin-based anthocyanins. Plant Cell Physiol. 2013, 54, 1684-1695. [CrossRef]

40. Noda, N.; Yoshioka, S.; Kishimoto, S.; Nakayama, M.; Douzono, M.; Tanaka, Y.; Aida, R. Generation of blue chrysanthemums by anthocyanin B-ring hydroxylation and glucosylation and its coloration mechanism. Sci. Adv. 2017, 3, e1602785. [CrossRef]

41. Holton, T.A.; Cornish, E.C. Genetics and biochemistry of anthocyanin biosynthesis. Plant Cell 1995, 7, 1071. [CrossRef]

42. Liu, Y.; Tikunov, Y.; Schouten, R.E.; Marcelis, L.F.; Visser, R.G.; Bovy, A. Anthocyanin biosynthesis and degradation mechanisms in Solanaceous vegetables: A review. Front. Chem. 2018, 6, 52. [CrossRef]

43. Seeram, N.P.; Momin, R.A.; Nair, M.G.; Bourquin, L.D. Cyclooxygenase inhibitory and antioxidant cyanidin glycosides in cherries and berries. Phytomedicine 2001, 8, 362-369. [CrossRef]

44. Robinson, G.M.; Robinson, R. A survey of anthocyanins. II. Biochem. J. 1932, 26, 1647. [CrossRef] [PubMed]

45. Katsumoto, Y.; Fukuchi-Mizutani, M.; Fukui, Y.; Brugliera, F.; Holton, T.A.; Karan, M.; Nakamura, N.; Yonekura-Sakakibara, K.; Togami, J.; Pigeaire, A. Engineering of the rose flavonoid biosynthetic pathway successfully generated blue-hued flowers accumulating delphinidin. Plant Cell Physiol. 2007, 48, 1589-1600. [CrossRef] [PubMed]

46. Itoh, Y.; Higeta, D.; Suzuki, A.; Yoshida, H.; Ozeki, Y. Excision of transposable elements from the chalcone isomerase and dihydroflavonol 4-reductase genes may contribute to the variegation of the yellow-flowered carnation (Dianthus caryophyllus). Plant Cell Physiol. 2002, 43, 578-585. [CrossRef] [PubMed]

47. Hong, Y.; Tang, X.; Huang, H.; Zhang, Y.; Dai, S. Transcriptomic analyses reveal species-specific light-induced anthocyanin biosynthesis in chrysanthemum. BMC Genom. 2015, 16, 202. [CrossRef] [PubMed] 
48. He, H.; Ke, H.; Keting, H.; Qiaoyan, X.; Silan, D. Flower colour modification of chrysanthemum by suppression of F3'H and overexpression of the exogenous Senecio cruentus F3'5'H gene. PLoS ONE 2013, 8, e74395. [CrossRef]

49. Liu, X.; Ahmad, N.; Yang, L.; Fu, T.; Kong, J.; Yao, N.; Dong, Y.; Wang, N.; Li, X.; Wang, F. Molecular cloning and functional characterization of chalcone isomerase from Carthamus tinctorius. AMB Express 2019, 9, 132. [CrossRef]

50. Li, S. Transcriptional control of flavonoid biosynthesis: Fine-tuning of the MYB-bHLH-WD40 (MBW) complex. Plant Signal. Behav. 2014, 9, e27522. [CrossRef]

51. Koes, R.; Verweij, W.; Quattrocchio, F. Flavonoids: A colorful model for the regulation and evolution of biochemical pathways. Trends Plant Sci. 2005, 10, 236-242. [CrossRef]

52. Yue, J.; Zhu, C.; Zhou, Y.; Niu, X.; Miao, M.; Tang, X.; Chen, F.; Zhao, W.; Liu, Y. Transcriptome analysis of differentially expressed unigenes involved in flavonoid biosynthesis during flower development of Chrysanthemum morifolium "Chuju”. Sci. Rep. 2018, 8, 13414. [CrossRef]

53. Hichri, I.; Barrieu, F.; Bogs, J.; Kappel, C.; Delrot, S.; Lauvergeat, V. Recent advances in the transcriptional regulation of the flavonoid biosynthetic pathway. J. Exp. Bot. 2011, 62, 2465-2483. [CrossRef]

54. Spelt, C.; Quattrocchio, F.; Mol, J.N.; Koes, R. Anthocyanin1 of petunia encodes a basic helix-loop-helix protein that directly activates transcription of structural anthocyanin genes. Plant Cell 2000, 12, 1619-1631. [CrossRef] [PubMed]

55. Elomaa, P.; Uimari, A.; Mehto, M.; Albert, V.A.; Laitinen, R.A.; Teeri, T.H. Activation of anthocyanin biosynthesis in Gerbera hybrida (Asteraceae) suggests conserved protein-protein and protein-promoter interactions between the anciently diverged monocots and eudicots. Plant Physiol. 2003, 133, 1831-1842. [CrossRef] [PubMed]

56. Nakatsuka, A.; Yamagishi, M.; Nakano, M.; Tasaki, K.; Kobayashi, N. Light-induced expression of basic helix-loop-helix genes involved in anthocyanin biosynthesis in flowers and leaves of Asiatic hybrid lily. Sci. Hortic. 2009, 121, 84-91. [CrossRef]

57. Yamagishi, M. Oriental hybrid lily Sorbonne homologue of LhMYB12 regulates anthocyanin biosyntheses in flower tepals and tepal spots. Mol. Breed. 2011, 28, 381-389. [CrossRef]

58. Matsui, K.; Umemura, Y.; Ohme-Takagi, M. AtMYBL2, a protein with a single MYB domain, acts as a negative regulator of anthocyanin biosynthesis in Arabidopsis. Plant J. 2008, 55, 954-967. [CrossRef] [PubMed]

59. Albert, N.W.; Davies, K.M.; Lewis, D.H.; Zhang, H.; Montefiori, M.; Brendolise, C.; Boase, M.R.; Ngo, H.; Jameson, P.E.; Schwinn, K.E. A conserved network of transcriptional activators and repressors regulates anthocyanin pigmentation in eudicots. Plant Cell 2014, 26, 962-980. [CrossRef]

60. Heim, M.A.; Jakoby, M.; Werber, M.; Martin, C.; Weisshaar, B.; Bailey, P.C. The basic helix-loop-helix transcription factor family in plants: A genome-wide study of protein structure and functional diversity. Mol. Biol. Evol. 2003, 20, 735-747. [CrossRef]

61. Ohno, S.; Deguchi, A.; Hosokawa, M.; Tatsuzawa, F.; Doi, M. A basic helix-loop-helix transcription factor DvIVS determines flower color intensity in cyanic dahlia cultivars. Planta 2013, 238, 331-343. [CrossRef]

62. Hsu, C.-C.; Chen, Y.-Y.; Tsai, W.-C.; Chen, W.-H.; Chen, H.-H. Three R2R3-MYB transcription factors regulate distinct floral pigmentation patterning in Phalaenopsis spp. Plant Physiol. 2015, 168, 175-191. [CrossRef]

63. Lim, S.-H.; Kim, D.-H.; Kim, J.K.; Lee, J.-Y.; Ha, S.-H. A radish basic helix-loop-helix transcription factor, RsTT8 acts a positive regulator for anthocyanin biosynthesis. Front. Plant Sci. 2017, 8, 1917. [CrossRef]

64. Liu, X.-F.; Yin, X.-R.; Allan, A.C.; Lin-Wang, K.; Shi, Y.-N.; Huang, Y.-J.; Ferguson, I.B.; Xu, C.-J.; Chen, K.-S. The role of MrbHLH1 and MrMYB1 in regulating anthocyanin biosynthetic genes in tobacco and Chinese bayberry (Myrica rubra) during anthocyanin biosynthesis. Plant Cell Tissue Organ Cult. 2013, 115, 285-298. [CrossRef]

65. Xiang, L.-L.; Liu, X.-F.; Li, X.; Yin, X.-R.; Grierson, D.; Li, F.; Chen, K.-S. A novel bHLH transcription factor involved in regulating anthocyanin biosynthesis in Chrysanthemums (Chrysanthemum morifolium Ramat.). PLoS ONE 2015, 10, e0143892. [CrossRef] [PubMed]

66. Hong, Y.; Li, M.; Dai, S. Ectopic expression of multiple chrysanthemum (Chrysanthemum $\times$ morifolium) R2R3-MYB transcription factor genes regulates anthocyanin accumulation in tobacco. Genes 2019, 10, 777. [CrossRef] [PubMed]

67. Du, H.; Feng, B.-R.; Yang, S.-S.; Huang, Y.-B.; Tang, Y.-X. The R2R3-MYB transcription factor gene family in maize. PLoS ONE 2012, 7, e37463. [CrossRef] [PubMed] 
68. Zimmermann, I.M.; Heim, M.A.; Weisshaar, B.; Uhrig, J.F. Comprehensive identification of Arabidopsis thaliana MYB transcription factors interacting with R/B-like BHLH proteins. Plant J. 2004, 40, 22-34. [CrossRef] [PubMed]

69. Laitinen, R.A.; Ainasoja, M.; Broholm, S.K.; Teeri, T.H.; Elomaa, P. Identification of target genes for a MYB-type anthocyanin regulator in Gerbera hybrida. J. Exp. Bot. 2008, 59, 3691-3703. [CrossRef]

70. Yamagishi, M.; Yoshida, Y.; Nakayama, M. The transcription factor LhMYB12 determines anthocyanin pigmentation in the tepals of Asiatic hybrid lilies (Lilium spp.) and regulates pigment quantity. Mol. Breed. 2012, 30, 913-925. [CrossRef]

71. Albert, N.W.; Lewis, D.H.; Zhang, H.; Schwinn, K.E.; Jameson, P.E.; Davies, K.M. Members of an R2R3-MYB transcription factor family in Petunia are developmentally and environmentally regulated to control complex floral and vegetative pigmentation patterning. Plant J. 2011, 65, 771-784. [CrossRef]

72. Liu, X.-F.; Xiang, L.-L.; Yin, X.-R.; Grierson, D.; Li, F.; Chen, K.-S. The identification of a MYB transcription factor controlling anthocyanin biosynthesis regulation in Chrysanthemum flowers. Sci. Hortic. 2015, 194, 278-285. [CrossRef]

73. Kee, E.S.; Naing, A.H.; Lim, S.H.; Han, J.S.; Kim, C.K. MYB transcription factor isolated from Raphanus sativus enhances anthocyanin accumulation in Chrysanthemum cultivars. 3 Biotech 2016, 6, 79. [CrossRef]

74. Xiang, L.; Liu, X.; Li, H.; Yin, X.; Grierson, D.; Li, F.; Chen, K. CmMYB\# 7, an R3 MYB transcription factor, acts as a negative regulator of anthocyanin biosynthesis in chrysanthemum. J. Exp. Bot. 2019, 70, 3111-3123. [PubMed]

75. Albert, N.W.; Lewis, D.H.; Zhang, H.; Irving, L.J.; Jameson, P.E.; Davies, K.M. Light-induced vegetative anthocyanin pigmentation in Petunia. J. Exp. Bot. 2009, 60, 2191-2202. [CrossRef] [PubMed]

76. Fox, A.R.; Soto, G.C.; Jones, A.M.; Casal, J.J.; Muschietti, J.P.; Mazzella, M.A. cry1 and GPA1 signaling genetically interact in hook opening and anthocyanin synthesis in Arabidopsis. Plant Mol. Biol. 2012, 80, 315-324. [CrossRef] [PubMed]

77. Winkel-Shirley, B. Flavonoid biosynthesis. A colorful model for genetics, biochemistry, cell biology, and biotechnology. Plant Physiol. 2001, 126, 485-493. [CrossRef]

78. Meng, X.; Xing, T.; Wang, X. The role of light in the regulation of anthocyanin accumulation in Gerbera hybrida. Plant Growth Regul. 2004, 44, 243. [CrossRef]

79. Kubasek, W.L.; Ausubel, F.M.; Shirley, B.W. A light-independent developmental mechanism potentiates flavonoid gene expression in Arabidopsis seedlings. Plant Mol. Biol. 1998, 37, 217-223. [CrossRef]

80. Katz, A.; Weiss, D. Photocontrol of chs gene expression in petunia flowers. Physiol. Plant. 1998, 102, $210-216$. [CrossRef]

81. Hong, Y.; Yang, L.-W.; Li, M.-L.; Dai, S.-L. Comparative analyses of light-induced anthocyanin accumulation and gene expression between the ray florets and leaves in chrysanthemum. Plant Physiol. Biochem. 2016, 103, 120-132. [CrossRef]

82. Dong, W.; Li, M.; Li, Z.; Li, S.; Zhu, Y.; Wang, Z. Transcriptome analysis of the molecular mechanism of Chrysanthemum flower color change under short-day photoperiods. Plant Physiol. Biochem. 2020, 146, 315-328. [CrossRef]

83. Weiss, D.; Halevy, A.H. The role of light reactions in the regulation of anthocyanin synthesis in Petunia corollas. Physiol. Plant. 1991, 81, 127-133. [CrossRef]

84. Ouzounis, T.; Fretté, X.; Rosenqvist, E.; Ottosen, C.-O. Spectral effects of supplementary lighting on the secondary metabolites in roses, chrysanthemums, and campanulas. J. Plant Physiol. 2014, 171, 1491-1499. [CrossRef] [PubMed]

85. Zheng, L.; van Labeke, M.-C. Chrysanthemum morphology, photosynthetic efficiency and antioxidant capacity are differentially modified by light quality. J. Plant Physiol. 2017, 213, 66-74. [CrossRef] [PubMed]

86. Lai, Y.-S.; Yamagishi, M.; Suzuki, T. Elevated temperature inhibits anthocyanin biosynthesis in the tepals of an Oriental hybrid lily via the suppression of LhMYB12 transcription. Sci. Hortic. 2011, 132, 59-65. [CrossRef]

87. Dela, G.; Or, E.; Ovadia, R.; Nissim-Levi, A.; Weiss, D.; Oren-Shamir, M. Changes in anthocyanin concentration and composition in "Jaguar" rose flowers due to transient high-temperature conditions. Plant Sci. 2003, 164, 333-340. [CrossRef]

88. Shvarts, M.; Weiss, D.; Borochov, A. Temperature effects on growth, pigmentation and post-harvest longevity of petunia flowers. Sci. Hortic. 1997, 69, 217-227. [CrossRef] 
89. Maekawa, S.; Nakamura, N. Studies on the coloration of carnation flowers. VII. The effects of temperature on the coloration and pigmentation for the intact flower and plant growth. J. Jpn. Soc. Hortic. Sci. 1977, 45, 375-382. [CrossRef]

90. Carvalho, S.M.P.; Abi-Tarabay, H.; Heuvelink, E. Temperature affects Chrysanthemum flower characteristics differently during three phases of the cultivation period. J. Hortic. Sci. Biotechnol. 2005, 80, 209-216. [CrossRef]

91. Nozaki, K.; Takamura, T.; Fukai, S. Effects of high temperature on flower colour and anthocyanin content in pink flower genotypes of greenhouse chrysanthemum (Chrysanthemum morifolium Ramat.). J. Hortic. Sci. Biotechnol. 2006, 81, 728-734. [CrossRef]

92. Huh, E.; Shin, H.; Choi, S.; Kwon, O.; Lee, Y. Theraiosusceptible developmental stage in anthocyanin accumulation and color response to high temperature in red chrysanthemum cultivars. Korean J. Hortic. Sci. Technol. 2008, 26, 357-361.

93. Puangkrit, T.; Narumi-Kawasaki, T.; Takamura, T.; Fukai, S. Inflorescence Developmental Stage-Specific High Temperature Effect on Petal Pigmentation in Chrysanthemum. Environ. Control Biol. 2018, 56, 99-106. [CrossRef]

94. Spelt, C.; Quattrocchio, F.; Mol, J.; Koes, R. Anthocyanin1 of petunia controls pigment synthesis, vacuolar $\mathrm{pH}$, and seed coat development by genetically distinct mechanisms. Plant Cell 2002, 14, 2121-2135. [CrossRef] [PubMed]

95. Cavallini, E.; Zenoni, S.; Finezzo, L.; Guzzo, F.; Zamboni, A.; Avesani, L.; Tornielli, G.B. Functional diversification of grapevine MYB5a and MYB5b in the control of flavonoid biosynthesis in a petunia anthocyanin regulatory mutant. Plant Cell Physiol. 2014, 55, 517-534. [CrossRef] [PubMed]

96. Schmitzer, V.; Veberic, R.; Osterc, G.; Stampar, F. Color and phenolic content changes during flower development in groundcover rose. J. Am. Soc. Hortic. Sci. 2010, 135, 195-202. [CrossRef]

97. Zhao, D.; Hao, Z.; Wang, J.; Tao, J. Effects of $\mathrm{pH}$ in irrigation water on plant growth and flower quality in herbaceous peony (Paeonia lactiflora Pall.). Sci. Hortic. 2013, 154, 45-53. [CrossRef]

98. Fukada-Tanaka, S.; Inagaki, Y.; Yamaguchi, T.; Saito, N.; Iida, S. Colour-enhancing protein in blue petals. Nature 2000, 407, 581. [CrossRef]

99. Yoshida, K.; Mori, M.; Kondo, T. Blue flower color development by anthocyanins: From chemical structure to cell physiology. Nat. Prod. Rep. 2009, 26, 884-915. [CrossRef]

100. Rusishvili, M.; Grisanti, L.; Laporte, S.; Micciarelli, M.; Rosa, M.; Robbins, R.J.; Collins, T.; Magistrato, A.; Baroni, S. Unraveling the molecular mechanisms of color expression in anthocyanins. Phys. Chem. Chem. Phys. 2019, 21, 8757-8766. [CrossRef]

101. Weiss, D.; van der Luit, A.; Knegt, E.; Vermeer, E.; Mol, J.N.; Kooter, J.M. Identification of endogenous gibberellins in petunia flowers (induction of anthocyanin biosynthetic gene expression and the antagonistic effect of abscisic acid). Plant Physiol. 1995, 107, 695-702. [CrossRef]

102. Schmitzer, V.; Veberic, R.; Stampar, F. Prohexadione-Ca application modifies flavonoid composition and color characteristics of rose (Rosa hybrida L.) flowers. Sci. Hortic. 2012, 146, 14-20. [CrossRef]

103. Rademacher, W. Growth retardants: Effects on gibberellin biosynthesis and other metabolic pathways. Annu. Rev. Plant Biol. 2000, 51, 501-531. [CrossRef]

104. Menhenett, R. Comparison of a new triazole retardant paclobutrazol (PP 333) with ancymidol, chlorphonium chloride, daminozide and piproctanyl bromide, on stem extension and inflorescence development in Chrysanthemum morifolium Ramat. Sci. Hortic. 1984, 24, 349-358. [CrossRef]

105. Roepke, J.; Jean, T.; Perkel, K.J.; Blom, T.; Bozzo, G.G. Daminozide alters anthocyanin metabolism in ray florets of bronze chrysanthemum (Chrysanthemum morifolium Ramat.). J. Plant Growth Regul. 2013, 32, 453-460. [CrossRef]

106. Hodaei, M.; Rahimmalek, M.; Arzani, A.; Talebi, M. The effect of water stress on phytochemical accumulation, bioactive compounds and expression of key genes involved in flavonoid biosynthesis in Chrysanthemum morifolium L. Ind. Crops Prod. 2018, 120, 295-304. [CrossRef]

107. Kim, Y.-S.; Sung, S.Y.; Jo, Y.D.; Lee, H.-J.; Kim, S.H. Effects of gamma ray dose rate and sucrose treatment on mutation induction in chrysanthemum. Eur. J. Hortic. Sci. 2016, 81, 212-218. [CrossRef]

108. Okamura, M.; Hase, Y.; Furusawa, Y.; Tanaka, A. Tissue-dependent somaclonal mutation frequencies and spectra enhanced by ion beam irradiation in chrysanthemum. Euphytica 2015, 202, 333-343. [CrossRef] 
109. Ryu, J.; Nam, B.; Kim, B.-R.; Kim, S.H.; Jo, Y.D.; Ahn, J.-W.; Kim, J.-B.; Jin, C.H.; Han, A.-R. Comparative analysis of phytochemical composition of gamma-irradiated mutant cultivars of Chrysanthemum morifolium. Molecules 2019, 24, 3003. [CrossRef]

110. Taiz, L.; Zeiger, E.; Møller, I.M.; Murphy, A. Plant Physiology and Development; Sinauer Associates: Sunderland, MA, USA, 2015.

111. Marschner, H. Marschner's Mineral Nutrition of Higher Plants; Academic Press: Cambridge, MA, USA, 2011.

112. Vanek, V.; Balik, J.; Cerny, J.; Pavliik, M.; Pavlikova, D.; Tlustos, P.; Valtera, J. The Nutrition of Horticultural Plants; Academic Press: Prague, Czech Republic, 2012.

113. Burchi, G.; Prisa, D.; Ballarin, A.; Menesatti, P. Improvement of flower color by means of leaf treatments in lily. Sci. Hortic. 2010, 125, 456-460. [CrossRef]

114. Kishi-Kaboshi, M.; Aida, R.; Sasaki, K. Generation of gene-edited Chrysanthemum morifolium using multicopy transgenes as targets and markers. Plant Cell Physiol. 2017, 58, 216-226.

115. Zhang, M.; Huang, H.; Wang, Q.; Dai, S. Cross breeding new cultivars of early-flowering multiflora chrysanthemum based on mathematical analysis. HortScience 2018, 53, 421-426. [CrossRef]

116. Anderson, N.O.; Ascher, P.D.; Fritz, V.; Rohwer, C.; Poppe, S.; Yao, S.; Johnson, P.; Klossner, L.; Eash, N. Chrysanthemum $\times$ grandiflorum MN Sel'n. 90-275-27 groundcover garden chrysanthemum. HortScience 2016, 51, 451-455. [CrossRef]

117. Cheng, X.; Chen, S.; Chen, F.; Deng, Y.; Fang, W.; Tang, F.; Liu, Z.; Shao, W. Creating novel chrysanthemum germplasm via interspecific hybridization and backcrossing. Euphytica 2011, 177, 45-53. [CrossRef]

118. Lim, J.; Shin, H.; Park, S.; Cho, H.; Rhee, H.; Kim, M.; Joung, H.; Yae, B. A spray chrysanthemum,"Secret Pink" with early blooming, long vase life, multi-floret, single flower type, and pink petals for cut flower. Korean J. Hortic. Sci. Technol. 2012, 30, 101-105. [CrossRef]

119. Anderson, N.O.; Gesick, E.; Fritz, V.; Rohwer, C.; Yao, S.; Johnson, P.; Poppe, S.; Liedl, B.E.; Klossner, L.; Eash, N. Mammoth ${ }^{\mathrm{TM}}$ series garden chrysanthemum 'Lavender Daisy'. HortScience 2014, 49, 1600-1604. [CrossRef]

120. Anderson, N.O.; Ascher, P.D.; Fritz, V.; Rohwer, C.; Poppe, S.; Yao, S.; Johnson, P.; Liedl, B.E.; Reith-Rozelle, J.; Klossner, L. Chrysanthemum $\times$ hybridum Mammoth ${ }^{\mathrm{TM}}{ }^{`}$ Dark Bronze Daisy' garden chrysanthemum. HortScience 2015, 50, 1260-1264. [CrossRef]

121. Aida, R.; Douzono, M.; Yoshioka, S.; Noda, N.; Tsuda, M.; Ohsawa, R. Inheritance of Bluish Flower Color of Transgenic Chrysanthemum by Interspecific Hybrids. Jpn. Agric. Res. Q. 2018, 52, 339-345. [CrossRef]

122. Lim, J.; Park, S.; Cho, H.; Rhee, H.; Kim, M.; Joung, H.; Shin, H. A new spray chrysanthemum cultivar, "Pink PangPang" with resistant to white rust, pompon type, and light pink color \& pink center for cut flower. Korean J. Breed. Sci. 2007, 39, 520-521.

123. Kim, W.H.; Park, P.H.; Jung, J.A.; Park, K.Y.; Suh, J.-N.; Kwon, O.K.; Yoo, B.S.; Lee, S.Y.; Park, P.M.; Choi, Y.J. Achievement of Flower Breeding in Korea and its Prospects. Korean Soc. Breed. Sci. 2020, 52, 161-169. [CrossRef]

124. Sobel, J.M.; Streisfeld, M.A. Flower color as a model system for studies of plant evo-devo. Front. Plant Sci. 2013, 4, 321. [CrossRef]

125. Wessinger, C.A. A genetic route to yellow flowers. New Phytol. 2015, 206, 1193-1195. [CrossRef]

126. Comings, D.E.; MacMurray, J.P. Molecular heterosis: A review. Mol. Genet. Metab. 2000, 71, 19-31. [CrossRef]

127. Su, J.; Jiang, J.; Zhang, F.; Liu, Y.; Ding, L.; Chen, S.; Chen, F. Current achievements and future prospects in the genetic breeding of chrysanthemum: A review. Hortic. Res. 2019, 6, 1-19. [CrossRef] [PubMed]

128. Sumitomo, K.; Shirasawa, K.; Isobe, S.; Hirakawa, H.; Hisamatsu, T.; Nakano, Y.; Yagi, M.; Ohmiya, A. Genome-wide association study overcomes the genome complexity in autohexaploid chrysanthemum and tags SNP markers onto the flower color genes. Sci. Rep. 2019, 9, 1-9. [CrossRef] [PubMed]

129. Won, S.Y.; Kim, J.S.; Kang, S.H.; Sohn, S.H. Current status and prospects of chrysanthemum genomics. J. Plant Biotechnol. 2016, 43, 272-280. [CrossRef]

130. Song, C.; Liu, Y.; Song, A.; Dong, G.; Zhao, H.; Sun, W.; Ramakrishnan, S.; Wang, Y.; Wang, S.; Li, T. The Chrysanthemum nankingense genome provides insights into the evolution and diversification of chrysanthemum flowers and medicinal traits. Mol. Plant 2018, 11, 1482-1491. [CrossRef] 
131. Hirakawa, H.; Sumitomo, K.; Hisamatsu, T.; Nagano, S.; Shirasawa, K.; Higuchi, Y.; Kusaba, M.; Koshioka, M.; Nakano, Y.; Yagi, M. De novo whole-genome assembly in Chrysanthemum seticuspe, a model species of Chrysanthemums, and its application to genetic and gene discovery analysis. DNA Res. 2019, 26, 195-203. [CrossRef]

132. Van Geest, G.; Bourke, P.M.; Voorrips, R.E.; Marasek-Ciolakowska, A.; Liao, Y.; Post, A.; van Meeteren, U.; Visser, R.G.; Maliepaard, C.; Arens, P. An ultra-dense integrated linkage map for hexaploid chrysanthemum enables multi-allelic QTL analysis. Theor. Appl. Genet. 2017, 130, 2527-2541. [CrossRef]

133. Thornsberry, J.M.; Goodman, M.M.; Doebley, J.; Kresovich, S.; Nielsen, D.; Buckler, E.S. Dwarf8 polymorphisms associate with variation in flowering time. Nat. Genet. 2001, 28, 286-289. [CrossRef]

134. Su, J.; Zhang, F.; Li, P.; Guan, Z.; Fang, W.; Chen, F. Genetic variation and association mapping of waterlogging tolerance in chrysanthemum. Planta 2016, 244, 1241-1252. [CrossRef]

135. Fu, X.; Su, J.; Yu, K.; Cai, Y.; Zhang, F.; Chen, S.; Fang, W.; Fadi, C.; Guan, Z. Genetic variation and association mapping of aphid (Macrosiphoniella sanbourni) resistance in chrysanthemum (Chrysanthemum morifolium Ramat.). Euphytica 2018, 214, 21. [CrossRef]

136. Li, P.; Su, J.; Guan, Z.; Fang, W.; Chen, F.; Zhang, F. Association analysis of drought tolerance in cut chrysanthemum (Chrysanthemum morifolium Ramat.) at seedling stage. 3 Biotech 2018, 8, 226. [CrossRef]

137. Li, P.; Zhang, F.; Chen, S.; Jiang, J.; Wang, H.; Su, J.; Fang, W.; Guan, Z.; Chen, F. Genetic diversity, population structure and association analysis in cut chrysanthemum (Chrysanthemum morifolium Ramat.). Mol. Genet. Genom. 2016, 291, 1117-1125. [CrossRef] [PubMed]

138. Chong, X.; Zhang, F.; Wu, Y.; Yang, X.; Zhao, N.; Wang, H.; Guan, Z.; Fang, W.; Chen, F. A SNP-enabled assessment of genetic diversity, evolutionary relationships and the identification of candidate genes in chrysanthemum. Genome Biol. Evol. 2016, 8, 3661-3671. [CrossRef] [PubMed]

139. Miyazaki, K.; Suzuki, K.-I.; Iwaki, K.; Kusumi, T.; Abe, T.; Yoshida, S.; Fukui, H. Flower pigment mutations induced by heavy ion beam irradiation in an interspecific hybrid of Torenia. Plant Biotechnol. 2006, 23, 163-167. [CrossRef]

140. Maluszynski, M.; Ahloowalia, B.S.; Sigurbjörnsson, B. Application of in vivo and in vitro mutation techniques for crop improvement. Euphytica 1995, 85, 303-315. [CrossRef]

141. Predieri, S. Mutation induction and tissue culture in improving fruits. Plant Cell Tissue Organ Cult. 2001, 64, 185-210. [CrossRef]

142. Ma, H.; Pooler, M.; Griesbach, R. Anthocyanin regulatory/structural gene expression in Phalaenopsis. J. Am. Soc. Hortic. Sci. 2009, 134, 88-96. [CrossRef]

143. Mol, J.; Grotewold, E.; Koes, R. How genes paint flowers and seeds. Trends Plant Sci. 1998, 3, $212-217$. [CrossRef]

144. Nakatsuka, T.; Nishihara, M.; Mishiba, K.; Yamamura, S. Two different mutations are involved in the formation of white-flowered gentian plants. Plant Sci. 2005, 169, 949-958. [CrossRef]

145. Mato, M.; Onozaki, T.; Ozeki, Y.; Higeta, D.; Itoh, Y.; Yoshimoto, Y.; Ikeda, H.; Yoshida, H.; Shibata, M. Flavonoid biosynthesis in white-flowered Sim carnations (Dianthus caryophyllus). Sci. Hortic. 2000, 84, 333-347. [CrossRef]

146. Tanaka, A.; Shikazono, N.; Hase, Y. Studies on biological effects of ion beams on lethality, molecular nature of mutation, mutation rate, and spectrum of mutation phenotype for mutation breeding in higher plants. J. Radiat. Res. 2010, 51, 223-233. [CrossRef]

147. Broertjes, C.; Koene, P.; Van Veen, J. A mutant of a mutant of a mutant of a ... : Irradiation of progressive radiation-induced mutants in a mutation-breeding programme with Chrysanthemum morifolium Ram. Euphytica 1980, 29, 525-530. [CrossRef]

148. Van Harten, A.M. Mutation Breeding: Theory and Practical Applications; Cambridge University Press: Cambridge, UK, 1998.

149. Park, I.; Lee, G.; Kim, D.; Chung, S.; Kim, J.; Song, H.; Goo, D.; Kang, S. Mutation breeding of a spray chrysanthemum "Argus" by gamma-ray irradiation and tissue culture. Flower Res. J 2007, 15, 52-57.

150. Datta, S.K.; Chakrabarty, D. Management of chimera and in vitro mutagenesis for development of new flower color/shape and chlorophyll variegated mutants in Chrysanthemum. Inducted Plant Mutat. Genom. Era 2009, 1, 303-305. 
151. Chung, S.J.; Lee, G.-J.; Lee, H.J.; Kim, J.-B.; Kim, D.S.; Kang, S.-Y. Isolation of a leucoanthocyanidin dioxygenase (LDOX) gene from a spray-type chrysanthemum (Dendranthema $\times$ grandiflorum) and its colored mutants. Korean J. Hortic. Sci. Technol. 2010, 28, 818-827.

152. Nagatomi, S.; Yamaguchi, H.; Degi, K.; Morishita, T.; Watanabe, H.; Tanaka, A. Six mutant varieties induced by ion beams in chrysanthemum. In The Institute of Radiation Breeding; Genetic Resources Center: Ibaraki, Japan, 2003.

153. Yamaguchi, H.; Shimizu, A.; Hase, Y.; Tanaka, A.; Shikazono, N.; Degi, K.; Morishita, T. Effects of ion beam irradiation on mutation induction and nuclear DNA content in chrysanthemum. Breed. Sci. 2010, 60, 398-404. [CrossRef]

154. Wiedenheft, B.; Sternberg, S.H.; Doudna, J.A. RNA-guided genetic silencing systems in bacteria and archaea. Nature 2012, 482, 331-338. [CrossRef]

155. Zhang, B.; Yang, X.; Yang, C.; Li, M.; Guo, Y. Exploiting the CRISPR/Cas9 system for targeted genome mutagenesis in petunia. Sci. Rep. 2016, 6, 20315. [CrossRef]

156. Xu, J.; Kang, B.C.; Naing, A.H.; Bae, S.J.; Kim, J.S.; Kim, H.; Kim, C.K. CRISPR/Cas9-mediated editing of 1-aminocyclopropane-1-carboxylate oxidase1 enhances Petunia flower longevity. Plant Biotechnol. J. 2020, 18, 287-297. [CrossRef]

157. Subburaj, S.; Chung, S.J.; Lee, C.; Ryu, S.-M.; Kim, D.H.; Kim, J.-S.; Bae, S.; Lee, G.-J. Site-directed mutagenesis in Petuniax hybrida protoplast system using direct delivery of purified recombinant Cas9 ribonucleoproteins. Plant Cell Rep. 2016, 35, 1535-1544. [CrossRef]

158. Sun, L.; Kao, T.-H. CRISPR/Cas9-mediated knockout of PiSSK1 reveals essential role of S-locus F-box protein-containing SCF complexes in recognition of non-self S-RNases during cross-compatible pollination in self-incompatible Petunia inflata. Plant Reprod. 2018, 31, 129-143. [CrossRef]

159. Yan, R.; Wang, Z.; Ren, Y.; Li, H.; Liu, N.; Sun, H. Establishment of Efficient Genetic Transformation Systems and Application of CRISPR/Cas9 Genome Editing Technology in Lilium pumilum DC. Fisch. and Lilium longiflorum White Heaven. Int. J. Mol. Sci. 2019, 20, 2920. [CrossRef] [PubMed]

160. Tong, C.G.; Wu, F.H.; Yuan, Y.H.; Chen, Y.R.; Lin, C.S. High-efficiency CRISPR/Cas-based editing of Phalaenopsis orchid MADS genes. Plant Biotechnol. J. 2020, 18, 889-891. [CrossRef] [PubMed]

161. Nishihara, M.; Higuchi, A.; Watanabe, A.; Tasaki, K. Application of the CRISPR/Cas9 system for modification of flower color in Torenia fournieri. BMC Plant Biol. 2018, 18, 1-9. [CrossRef] [PubMed]

162. Watanabe, K.; Kobayashi, A.; Endo, M.; Sage-Ono, K.; Toki, S.; Ono, M. CRISPR/Cas9-mediated mutagenesis of the dihydroflavonol-4-reductase-B (DFR-B) locus in the Japanese morning glory Ipomoea (Pharbitis) nil. Sci. Rep. 2017, 7, 1-9. [CrossRef]

163. Watanabe, K.; Oda-Yamamizo, C.; Sage-Ono, K.; Ohmiya, A.; Ono, M. Alteration of flower colour in Ipomoea nil through CRISPR/Cas9-mediated mutagenesis of carotenoid cleavage dioxygenase 4. Transgenic Res. 2018, 27, 25-38. [CrossRef]

164. Kim, D.-H.; Park, S.; Lee, J.-Y.; Ha, S.-H.; Lim, S.-H. Enhancing flower color through simultaneous expression of the B-peru and mPAP1 transcription factors under control of a flower-specific promoter. Int. J. Mol. Sci. 2018, 19, 309. [CrossRef]

165. Chandler, S.F.; Sanchez, C. Genetic modification; The development of transgenic ornamental plant varieties. Plant Biotechnol. J. 2012, 10, 891-903. [CrossRef]

166. Seitz, C.; Eder, C.; Deiml, B.; Kellner, S.; Martens, S.; Forkmann, G. Cloning, functional identification and sequence analysis of flavonoid $3^{\prime}$-hydroxylase and flavonoid $3^{\prime}, 5^{\prime}$-hydroxylase cDNAs reveals independent evolution of flavonoid 3', 5'-hydroxylase in the Asteraceae family. Plant Mol. Biol. 2006, 61, 365-381. [CrossRef]

167. Tanaka, Y. Flower colour and cytochromes P450. Phytochem. Rev. 2006, 5, 283-291. [CrossRef]

168. Brugliera, F.; Tao, G.-Q.; Tems, U.; Kalc, G.; Mouradova, E.; Price, K.; Stevenson, K.; Nakamura, N.; Stacey, I.; Katsumoto, Y. Violet/blue chrysanthemums-Metabolic engineering of the anthocyanin biosynthetic pathway results in novel petal colors. Plant Cell Physiol. 2013, 54, 1696-1710. [CrossRef]

169. Onozaki, T.; Mato, M.; Shibata, M.; Ikeda, H. Differences in flower color and pigment composition among white carnation (Dianthus caryophyllus L.) cultivars. Sci. Hortic. 1999, 82, 103-111. [CrossRef]

170. Spribille, R.; Forkmann, G. Genetic control of chalcone synthase activity in flowers of Antirrhinum majus. Phytochemistry 1982, 21, 2231-2234. [CrossRef] 
171. Park, C.; Chae, S.; Park, S.-Y.; Kim, J.; Kim, Y.; Chung, S.; Arasu, M.; Al-Dhabi, N.; Park, S. Anthocyanin and carotenoid contents in different cultivars of chrysanthemum (Dendranthema grandiflorum Ramat.) flower. Molecules 2015, 20, 11090-11102. [CrossRef]

172. Sasaki, K.; Mitsuda, N.; Nashima, K.; Kishimoto, K.; Katayose, Y.; Kanamori, H.; Ohmiya, A. Generation of expressed sequence tags for discovery of genes responsible for floral traits of Chrysanthemum morifolium by next-generation sequencing technology. BMC Genom. 2017, 18, 683.

173. Wang, K.; Bai, Z.-Y.; Liang, Q.-Y.; Liu, Q.-L.; Zhang, L.; Pan, Y.-Z.; Liu, G.-L.; Jiang, B.-B.; Zhang, F.; Jia, Y. Transcriptome analysis of chrysanthemum (Dendranthema grandiflorum) in response to low temperature stress. BMC Genom. 2018, 19, 319. [CrossRef]

(C) 2020 by the authors. Licensee MDPI, Basel, Switzerland. This article is an open access article distributed under the terms and conditions of the Creative Commons Attribution (CC BY) license (http://creativecommons.org/licenses/by/4.0/). 